\title{
UNIVERSITYOF
}

FORWARD

THINKING

WESTMINSTER用

WestminsterResearch

http://www.westminster.ac.uk/westminsterresearch

\section{The motives and performance of cross-border acquirers from emerging economies: Comparison between Chinese and Indian firms}

Salaber, Julie and Rao-Nicholson, Rekha

NOTICE: this is the authors' version of a work that was accepted for publication in International Business Review. Changes resulting from the publishing process, such as peer review, editing, corrections, structural formatting, and other quality control mechanisms may not be reflected in this document. Changes may have been made to this work since it was submitted for publication. A definitive version was subsequently published in International Business Review, 22 (6) 963-980 0969-5931.

International Business Review is available online at:

https://dx.doi.org/10.1016/j.ibusrev.2013.02.003

(C) 2013. This manuscript version is made available under the CC-BY-NC-ND 4.0 license http://creativecommons.org/licenses/by-nc-nd/4.0/

The WestminsterResearch online digital archive at the University of Westminster aims to make the research output of the University available to a wider audience. Copyright and Moral Rights remain with the authors and/or copyright owners.

Whilst further distribution of specific materials from within this archive is forbidden, you may freely distribute the URL of WestminsterResearch: ((http://westminsterresearch.wmin.ac.uk/).

In case of abuse or copyright appearing without permission e-mail repository@westminster.ac.uk 


\title{
The motives and performance of cross-border acquirers from emerging economies: Comparison between Chinese and Indian firms
}

\author{
Rekha Rao Nicholson and Julie Salaber
}

\begin{abstract}
During the recent decade, the world has witnessed the rapid growth of MNEs from emerging economies. Their increasing participation in cross-border mergers and acquisitions has raised great attention in the extant literature. This study evaluates the value creation from these cross-border transactions from two representative emerging countries, namely China and India, and determines factors that result in the different performance of these international acquisition activities. Crossborder acquisitions conducted by these countries' companies indeed lead to significant shareholder wealth creation. Furthermore, Indian shareholders are more likely to benefit from deals in small cultural distance countries, while Chinese investors gain from the cross-border expansion of manufacturing companies. Location also affects the performance of cross-border acquisitions, with acquisitions into developed countries generating higher returns to shareholders. Our sample consists of 203 Indian and 63 Chinese cross-border deals over the period 2000-2010 and our results hold after controlling for various deal-level and firm-level characteristics.
\end{abstract}

Keywords: Cross-border acquisitions; Short-term performance; China; India; Competitive advantage; Cultural distance 


\section{Introduction}

Historically, in their efforts to internationalize, emerging-market (EM) firms have used strategies ranging from exports to equity investment (Guillen, 2000) and joint ventures (Khanna \& Palepu, 2000). The recent decades have witnessed the dramatic rise of firms from emerging economies, especially those from China and India, adopting cross-border mergers and acquisitions (M\&As) as the main approach to realize internationalization (Athreye \& Kapur, 2009; Aulakh, Kotabe, \& Teegen, 2000; Gubbi, Aulakh, Ray, Sarkar, \& Chittoor, 2010; UNCTAD, 2011). According to the World Investment Report 2010, the outward foreign direct investment (FDI) from emerging economies has increased to a record high of $25 \%$ of the global total (UNCTAD, 2010). The increasing number of cross-border acquisitions by EM firms provides the impetus for growing outward investment (UNCTAD, 2010). Outbound cross-border acquisitions by EM firms have increased from $\$ 37$ billion in 2004 to $\$ 182$ billion in 2008 - a staggering rise of 392\%; and the $\$ 182$ billion (for 2008) makes up $66 \%$ of the total FDI outflows from emerging countries (UNCTAD, 2009). During the first decade of $21^{\text {st }}$ century, Chinese firms completed 450 outbound acquisitions, whereas Indian firms acquired 812 foreign companies (UNCTAD, 2010). Figure 1 shows that in China the number of completed crossborder M\&As increased from 36 in 2000 to 135 in 2010 and the value of deals jumped to over US\$32 billion in 2010. Meanwhile in India (Figure 2), the number of deals has also increased from 54 in 2000 to 133 in 2010 and the value of deals exceeds US\$23 billion.

[Figures 1 and 2 about here]

So far however, despite this booming trend, researchers fail to address whether the extant hypothesized internationalization theories (Dunning, 2001; von Eije \& Wiegerinck, 2010) are applicable to acquirers from developing economies since many differences exist between developed and developing markets. Also, the issues whether overseas M\&As by EM firms can create value for the bidders and which factors play an important role in the M\&A performance are worth paying attention to. Accordingly, this paper mainly uses event study metrics to investigate and compare the short-term performance of cross-border acquirers in China and India and puts forward the possible explanations for the differences. We had borrowed from two strands of theories to frame our arguments, namely the resource-based view (Accenture, 2006; Barney, 1991; Deng, 2007; Wang \& Boateng, 2007) which talks about strategic resource seeking, and Dunning's seminal work (Dunning, 2001) which relates to market seeking activities linked to fast entry into foreign markets (Buckley, et al., 2007).

The proposed contribution of this paper is threefold. First, the existing literature lacks comparative studies on cross-border M\&A performance in emerging markets (Aybar \& Ficici, 2009; Bhagat, Malhotra, \& Zhu, 2011) though several of these countries have been studied singularly (Gubbi, et al., 2010; Wang \& Boateng, 2007; Zhang, Zhou, \& Ebbers, 2011). Second, this paper invokes the major motives for cross-border M\&As undertaken by EM firms (Deng, 2007; Deng, 2009; Li, 2007; Luo \& Tung, 2007; Sun, Peng, Ren, \& Yan, 2012; Wang \& Boateng, 2007). These 
factors help us understand the underlying reasons that have led to cross-border acquisitions by Chinese and Indian companies and identify "the conditions under which acquisitions make sense as a path to superior performance" (King, Dalton, Daily, \& Covin, 2004). Third, our analysis mainly uses regression metrics to do the comparative work, which is rare in the international business literature. We firstly conduct an event study to compare the short-term performance of international acquisitions between Chinese and Indian markets. Then we use cross-sectional regressions to test the different patterns of cross-border acquisitions in both countries, and find the determinants that have an influential effect on their short-term performance.

The remainder of the paper is organized as follows. The next section provides a summary of the relevant literature and important theoretical frameworks that are essential to our understanding of the motivations and performance of cross-border M\&As in emerging economies. In Section 3, we compare the expected different features of overseas acquisitions between Chinese and Indian firms, and develop our hypotheses relative to their short-term performance. Section 4 outlines the sample and methodology applied, and Section 5 presents the empirical results. Section 6 provides concluding comments and discussion.

\section{Literature Review}

\subsection{Performance of cross-border M\&As}

The extensive literature on the short-term performance of bidders from developed markets (especially the U.S. market) finds that bidding firms earn negative abnormal returns on average (Kim, Haleblian, \& Finkelstein, 2011; Klossek, Linke, \& Nippa, 2012; Kobrin, 1979). The main argument for this finding is that corporate diversification is redundant as investors can hold diversified portfolios. Regarding cross-border M\&As, several papers investigate foreign investment of developed-country companies but the evidence is mixed. The short-term performance of U.S. bidders targeting a foreign company has been found to be either positive (Doukas \& Travlos, 1988; Kostova, Roth, \& Dacin, 2008) or negative (Ghemawat, 2001). Doukas and Travlos (1988) invoke the theory of corporate multinationalism to explain the positive abnormal return. Firms have a greater strategic advantage in international markets than investors. They can increase their market value by expanding their existing multinational network. However, Moeller and Schlingemann (2005) argue that international diversification can be considered as value decreasing (at least for shareholders) if the costs are higher than the benefits. These costs include greater competition for corporate control, increase in agency problems, greater complexity and inefficient cross-subsidization. In the U.K., international bidders do not earn any significant abnormal return around the announcement date, irrespective of the country of the target company (Gregory \& McCorriston, 2005). Finally, a Dutch study (Slangen, 2006) shows that the abnormal return actually depends on the level of post-acquisition integration.

In spite of increasing involvement of Chinese and Indian companies in cross-border activities, 
research on this topic is limited and results are not convincing. A cross-country study over 13 emerging markets (Aybar \& Ficici, 2009) finds that bidders earn a negative abnormal return when acquiring abroad. On the contrary, Bhagat, et al. (2011) study 698 cross-border acquisitions by bidders from 8 emerging countries and conclude that these acquirers experience a positive and significant market response around the announcement date. Similarly, Gubbi, et al. (2010) show that cross-border acquisitions from Indian companies earn a positive abnormal return over the period 2000-2007.

\subsection{Motives for cross-border M\&As}

The traditionally dominant theory of internationalization is the Dunning's $(1980,1988,1993)$ OLI paradigm based on the exploitation of three different advantages: Ownership, Location and Internationalization. Dunning (1993) suggests three main motives for foreign investments: foreign market seeking, efficiency seeking (i.e., cost reduction), and resource seeking. Since the rapid growth of cross-border M\&As from EM companies, scholars have investigated their motivations for internationalization and agree that this traditional analysis cannot totally explain the rise in crossborder M\&As from emerging markets (Athreye \& Kapur, 2009; Buckley, et al., 2007; Dunning \& Lundan, 2008; Gubbi, et al., 2010; Li, 2007; Mathews, 2006; Rui \& Yip, 2008; Sun, et al., 2012). Authors have applied Dunning's first motive (foreign market seeking) to developing-country FDI and suggest that EM firms become international acquirers "for traditional trade supporting reasons", e.g. to access distribution networks and to facilitate the export of domestic products (Buckley, et al., 2007). However, recent research suggests that the motives for EM firms to expand abroad are fundamentally different from those of developed-economy firms (Buckley, et al., 2007; Fortanier \& Tulder, 2009; Li, 2007; Luo \& Tung, 2007). For instance, Luo and Tung (2007) argue that EM firms pursuing overseas $M \& A s$ are driven by asset seeking rather than asset exploiting.

Thus the first motive for cross-border M\&As from EM companies is based on strategic resource seeking. The resource-based view literature suggests that capabilities and resources are the key determinants of a firm's competitive advantage (Barney, 1991). According to this resource-based theory, the key motivation for foreign acquisitions is to gain access to strategic assets such as natural resources, product differentiation, patent-protected technologies, superior managerial and marketing skills, as well as achieving economies of scale (Accenture, 2006; Athreye \& Kapur, 2009; Chen, 2008; Cui \& Jiang, 2010; Deng, 2007; Deng, 2009; Kumar, 2009; Rui \& Yip, 2008; Wang \& Boateng, 2007). Lacking such strategic resources, EM firms use cross-border M\&As as the most effective way to improve their competitive advantage and performance (Gubbi, et al., 2010). Moreover, global firms which aim at acquiring new assets and new capabilities tend to create more M\&A value than multinational enterprises (MNEs) pursuing a strategy based on the exploitation of their existing capabilities (Chittoor \& Ray, 2007). In other words, strategic assets are necessary to meet the needs for bolstering economic development at home and compete more effectively against their global rivals at home and abroad (Luo \& Tung, 2007; UNCTAD, 2006). This strategic resource seeking seems to 
be the main motivation of cross-border acquisitions for Chinese companies as nearly half of China's outbound investment is focused on securing natural resources (Dietz, Orr, \& Xing, 2008). In order to access advanced management and marketing skills, EM companies should be expected to target firms from developed markets, i.e., characterized by higher-quality complementary resources (Gubbi, et al., 2010). As suggested by Harrison, Hitt, Hoskisson, and Ireland (2001), high-value front-end capabilities and resources available in developed markets, when combined with the back-end low-cost capabilities in emerging markets, can create uniquely valuable resource combinations to achieve higher market valuation and globalization realization. Gubbi, et al. (2010) actually show that Indian bidders earn a higher return when targeting a more developed country.

Cross-border acquisitions by EM companies are also motivated by a fast entry to foreign markets. Many studies consider cross-border M\&As as the fastest means for MNEs, especially EM firms, to expand their product and consumer markets internationally (Belderbos, 2003; Chen \& Findlay, 2003; Deng, 2007; Deng, 2009; Li, 2007; Wang \& Boateng, 2007). The acceleration of globalization implies increased competition and shorter product life cycles; firms have to react quickly to stay in line with other competitors. In order to access new marketing network and potential clients, the takeover of an existing firm in a foreign market with an established distribution system is much easier and more preferable than building up a global organization from scratch (Chen \& Findlay, 2003). This is particularly true for EM companies targeting developed markets, as the costs of finding, negotiating and enforcing a cooperative agreement are much greater than the costs of direct control (Bowen \& Jones, 1986; Erramilli \& Rao, 1993; Hennart, 1989). Indeed the internationalization process can be more or less time-consuming, difficult and expensive depending on factors such as geographical, psychic or cultural distance and institutional constraints (Barkema, Bell, \& Pennings, 1996; Boateng \& Glaister, 2003; Luo \& Tung, 2007). For instance, a large body of literature suggests that cultural distance is relevant to cross-border acquisition performance (Antia, Lin, \& Pantzalis, 2007; Aybar \& Ficici, 2009; Brock, 2005; He, Bin, \& Chen, 2008; López-Duarte \& Vidal-Suárez, 2010; Malhotra, Sivakumar, \& Zhu, 2011; Morosini, 1998; Morosini, Shane, \& Singh, 1998; Steigner \& Sutton, 2011). Most MNEs use cross-border acquisitions as a fast and easy way to acquire strategic assets and enter new markets, but we argue that this ease of access is much greater for Indian bidders than for Chinese companies. Indeed, India is a commonwealth country due to its status of former British colony; hence it has long been influenced by western language, politics, business and culture. Thus Indian companies seeking to enter new markets, especially developed markets, will encounter a lower clash of culture (and thus benefit from a faster entry) than their Chinese counterparts (Buckley, Forsans, \& Munjal, 2012).

Overall, the reaction of EM shareholders to the announcement of cross-border acquisitions is mixed, and the motives for these foreign transactions appear to be fundamentally different than in the case of developed-country acquirers. 


\subsection{Other factors affecting $M \& A$ performance}

In order to genuinely explain the performance of cross-border M\&As from China and India, we need to control for other factors that are likely to affect any domestic or cross-border acquirer (both from developed and emerging countries). Following extensive literature on M\&A performance (Cakici, Hessel, \& Tandon, 1996; Ghemawat, 2001; Gubbi, et al., 2010; Lubatkin \& Chatterjee, 1991; Moeller \& Schlingemann, 2005), we use several control variables that have been found impacting bidder's abnormal returns. These factors are related to deal characteristics (mode of payment, percentage acquired, relative deal size and target status) and bidder characteristics (industry relatedness, prior presence and state ownership). We present here the literature behind these control variables.

\subsubsection{Mode of payment}

Extensive studies have illustrated that cash-financed M\&As yield positive abnormal returns, whereas stock-financed M\&As generate negative abnormal returns (Blackburn, Dark, \& Hanson, 1997; Brown \& Ryngaert, 1991; Faccio \& Masulis, 2005; Mann \& Kohli, 2009; Martynova \& Renneboog, 2008; Smith \& Kim, 1994). Information asymmetry about the true value of the acquirer's stock and the disciplinary role of debt incurred for cash financing are widely accepted as the reasons that cause this difference (Yook, 2003). Myers and Majluf (1984) consider the signaling role of equity. Due to information asymmetry in the imperfect market, a manager who has more information than investors knows more about the firm's value. Thus, if bad news is about to come, the manager will attempt to 'beat the market' by issuing overvalued equity. In other words, a firm offering stock as payment signals to the investors that the stock is overvalued. Jensen (1986) considers the disciplinary role of debt that can mitigate agency problems. Investors would have more confidence in the prospect of the deals since increasing debt commits managers to make more effort.

\subsubsection{Level of control}

Several studies consider the acquisition of a controlling stake as the opportunistic behavior of acquirers to capture strategic assets (Aybar \& Ficici, 2009; Moeller \& Schlingemann, 2005). For M\&As involving developed-economy acquirers and EM targets, Chari, Ouimet, and Tesar (2004) verify that the achievement of a controlling stake of the target firm has a positive and significant impact on the value of the acquiring firm. However, for cross-border M\&As undertaken by EM firms, Aybar and Ficici (2009) only find a positive impact of control level on the firm value in the univariate test, but fail to confirm the significance of the level of control in their multivariate analysis.

\subsubsection{Relative deal size}

It is generally believed that firms can achieve economies of scale in their production management, marketing, distribution, etc. through expanding their capital investments in related fields. The same logic applies to cross-border M\&As: successful cross-border transactions leading to large size may generate synergies that make post-acquisition firm value exceed the simple addition of the value of both firms (Lamacchia, 1997). Aybar and Ficici (2009) state that EM firms may also gain 
from increased market presence and capital exploration efficiency globally, which ultimately enhance their profitability. However, some researchers identify several drawbacks associated with investment size. Information asymmetry, even more challenging in cross-border transactions, leads to misidentification of synergies and overestimation of post-acquisition value (Aybar \& Ficici, 2009). Large deals may also take longer than expected, which could result in negative market reactions (Mulherin \& Boone, 2000). Empirically, the relative deal size is a significant factor for developedcountry acquirers (Moeller \& Schlingemann, 2005; Slangen, 2006; von Eije \& Wiegerinck, 2010) but not for EM multinationals (Aybar \& Ficici, 2009).

\subsubsection{Status of target}

Numerous studies investigate whether the performance of M\&As differs when targets are publicly listed companies or privately held (Aybar \& Ficici, 2009; Capron \& Shen, 2007; Gubbi, et al., 2010; Moeller \& Schlingemann, 2005; Yook, 2003). Key differences between private and public firms are the quantity and quality of information available to the public, as well as the ownership structure. Acquirers would pay more (and thus earn lower returns) if the target is listed since the transaction price needs to satisfy the interests of a diverse group of shareholders (Choi \& Russell, 2004; Fuller, Netter, \& Stegemoller, 2002). Overall, empirical studies find a significant premium for bidders targeting a private company compared to acquisitions of publicly listed companies (Aybar \& Ficici, 2009; Fuller, et al., 2002; Moeller \& Schlingemann, 2005). Gubbi, et al. (2010) do not find the status of the target to be a significant factor for Indian acquisitions.

\subsubsection{Industry Relatedness}

The potential of synergies depends, to a large extent, on the similarity between the target and acquirer industries. These similarities "facilitate strategic fit through production rationalization, economies of scale and scope, diffusion of know-how, and lower managerial slack" (Bertrand \& Zitouna, 2008). In other words, if the target and the acquirer belong to the same industry, operational and financial synergies are more likely to be achieved in the cross-border M\&As. Many studies have confirmed that a higher abnormal return is reported for related acquisitions than non-related ones (Akbulut \& Matsusaka, 2010; Denis, Denis, \& Yost, 2002; Moeller \& Schlingemann, 2005; Slangen, 2006).

\subsubsection{Prior presence}

The prior experience in the target industry and/or country is also an important factor that needs to be taken into account. According to Doukas and Travlos (1988), the positive-multinational-network hypothesis considers that the shares of the bidder are likely to experience greater impact from country- or industry-diversifying acquisitions. The authors find supporting evidence that the bidder firm can create larger abnormal returns when expanding into a new industry or a new country, especially in less developed countries. More recently, the evidence about the prior experience in the target country is mixed, i.e., this factor has been shown to be positive (Slangen, 2006), negative (von Eije \& Wiegerinck, 2010) or not significant (Aybar \& Ficici, 2009). 


\subsubsection{State-owned companies in China}

Although Chinese stock markets are entering the era of free float, many Chinese firms possessing critical industrial and financial resources are still controlled in majority by the central and local government. Such state-holding enterprises have large firm size, stable operating situation, and some of them have accumulated some experience of overseas operations through Greenfield investments. Therefore, they have a greater chance to conduct successful overseas M\&As compared to other companies. Besides, one major policy objective of the Chinese government is to promote competent enterprises to go global (Cai, 1999; Chen \& Findlay, 2003; Deng, 2007; Luo \& Tung, 2007; Luo, Xue, \& Han, 2010; Singh, 2009; Sun, et al., 2012), and state-holding enterprises are naturally more likely to expand abroad (Wang, Hong, Kafouros, \& Boateng, 2012) and receive support from the government (e.g. in financing large-scale M\&A transactions). However some principal-principal conflicts arise when the government is the majority owner, i.e., minority shareholders might have divergent interests and thus react negatively to a proposed cross-border M\&A deal. Chen and Young (2010) find supporting evidence for this principal-principal hypothesis. Comparatively, Indian firms have more open market mechanisms and friendly government policies, where private enterprises can easily finance their cross-border M\&As in the stock market (Accenture, 2006). Sun, et al. (2012) confirm that Chinese state-owned enterprises generally play the leading role in cross-border M\&As, whereas private enterprises play the leading role in India. We thus use this variable as control variable only for Chinese transactions.

\section{Hypotheses development}

Based on previous theory and evidence, we develop here several hypotheses related to the respective motivations of Chinese and Indian acquirers to target foreign companies, and the impact of such motives on the bidder's performance. Although Chinese and Indian foreign transactions share a number of common features, they also have significant differences. Common characteristics to China and India are for instance that $(i)$ the pace of growth in M\&A activity is strongly influenced by government policies (Athreye \& Kapur, 2009; Chen \& Findlay, 2003; Khanna \& Palepu, 2006; Luo \& Tung, 2007; Luo, et al., 2010; Nayyar, 2008; Sun, et al., 2012; Witt \& Lewin, 2007), (ii) the level of internationalization of large companies is still lower than that of most developed-country firms (Fortanier \& Tulder, 2009; Li, 2007), and (iii) most transactions in both countries are friendly purchase agreements (Sun, et al., 2012). However we argue that the primary motivation for Chinese and Indian companies going abroad is different and that such difference will be reflected in the shareholder reaction to the announcement of cross-border deals. According to the Accenture Report (2006) "Chinese firms invest heavily in emerging economies in Africa, Central Asia and Latin America, largely to secure the natural resources essential for their own economic growth", whereas Indian acquirers prefer to target firms in developed countries "to gain market share as well as to provide a platform for regional growth". 


\subsection{Competitive advantage and performance}

Applying the resource-based theory to Chinese and Indian companies, we argue that the key motivation for their foreign acquisitions is to gain access to strategic assets, but that Chinese and Indian acquirers are targeting different types of strategic assets. Chinese MNEs are more interested in gaining natural resources and superior managerial and marketing skills in order to improve their competitive advantage in manufactured products (Athreye \& Kapur, 2009; Chen, 2008; Cui \& Jiang, 2010; Deng, 2007; Deng, 2009; Kumar, 2009; Rui \& Yip, 2008; Wang, et al., 2012; Wang \& Boateng, 2007), whereas cross-border acquisitions from Indian companies primarily involve a technologyintensive industry (e.g. software and pharmaceutical) in which India has a high competitive advantage (Arora, Arunachalam, Asundi, \& Fernandes, 2001; Ethiraj, Kale, Krishnan, \& Singh, 2005; Miozzo \& Grimshaw, 2008; Sun, et al., 2012). In both cases, we want to test whether shareholders recognize and value this strategic resource seeking motive.

Dietz, et al. (2008) suggest that nearly half of China's FDI focuses on securing natural resources. Sun, et al. (2012) confirm that, in order to fuel their rapid economic growth, large Chinese companies need to consolidate their core competitive advantages which are cheap labor and rich natural resources. Chinese firms enjoy a comparative advantage in manufacturing-oriented industries and, considered the 'workshop of the world' China has the potential to become the dominant global supplier of manufactured goods. As a matter of fact, the majority of cross-border M\&As by Chinese firms occurs in the manufacturing industry, and more commonly carried out by state-owned enterprises (Athreye \& Kapur, 2009; Sun, et al., 2012). We thus investigate whether Chinese shareholders react positively to acquisition announcements from companies enjoying a competitive advantage (i.e., belonging to the manufacturing industry) and willing to consolidate natural resources important for their production. The market reaction should be positive if shareholders recognize and value this strategic resource seeking and competitive advantage.

\section{H1a: Chinese bidders experience more favorable abnormal returns when their main activity is in manufacturing.}

Rather than natural resources, Indian companies invest abroad in order to gain more advanced resources such as leading technologies and knowledge-based abilities (Buckley, et al., 2012). These foreign technological assets are known to improve the performance and competitive advantage of the firm (Tsang, Yip, \& Toh, 2008). Indeed Indian MNEs have a competitive advantage in business services, which are characterized by high customization, high intangibility, and simultaneity of production and consumption (Boddewyn, Halbrich, \& Perry, 1986; Zeithaml, Parasuraman, \& Berry, 1985). Moreover, human resources in service sector firms are mobile and easily re-trainable for alternative use (Erramilli \& Rao, 1993). Thus the benefits of cross-border acquisitions are potentially higher for service sector MNEs compared to non-service sector MNEs, and several service sector firms in India, especially in computer programming services, have experienced such benefits. For 
instance, the acquisitions of firms such as the US software company UII by Cyberspace (2001), German AD Solutions by India's leading software firm NIIT Ltd (2002), and British Alcatel SA's fraud management software unit by Subex Systems Ltd (2004) significantly expanded the bidder's markets and client bases. Thus we can test this strategic resource seeking motive the same way we tested it for China. We expect shareholders to recognize and value cross-border acquisitions from Indian companies enjoying a competitive advantage (i.e., in the service industry).

H1b: Indian bidders experience more favorable abnormal returns when their main activity is in the service industry.

\subsection{Developed target country and performance}

Another way to test the resource seeking hypothesis is to investigate whether Chinese and Indian shareholders react positively to acquisitions into developed countries characterized by higher-quality complementary resources (Buckley, et al., 2012). Indeed emerging market MNEs invest in more advanced countries to access or augment, rather than to exploit their ownership advantages (Dunning, 1998, 2006), thus acquiring assets with potential to create competitive advantages (Marinova, Child, $\&$ Marinov, 2011). Foreign acquisitions in developed countries are an efficient and fast way to acquire strategic or knowledge-based resources usually not available in the domestic market or in other emerging markets (Gubbi, et al., 2010). Moreover, high-value front-end capabilities and resources available in developed markets, combined with the back-end low-cost capabilities from emergingmarket MNEs can create uniquely valuable resource combinations to achieve higher market valuation (Harrison, et al., 2001).

Thus, driven by this strategic asset seeking, both Chinese and Indian acquirers would obtain greater value if targeting more developed countries as these transactions would help them garner strategic resources not readily available at home (Chan, Isobe, \& Makino, 2008; Gubbi, et al., 2010). Hence we expect that acquisitions into developed countries are valued positively by their shareholders.

H2: Chinese and Indian bidders experience more favorable abnormal returns when they target more advanced economies.

\subsection{Moderating effect of cultural distance on fast entry}

Finally, we test how the other main motive for cross-border M\&As (fast entry to foreign markets) is influenced by the cultural distance between the target and bidder countries. EM companies use cross-border acquisitions as a fast and easy way to enter new markets and acquire strategic assets (Boateng, Qian, \& Tianle, 2008). Although this mode of entry is considered as being the quickest, easiest and most preferable means to access new marketing network and potential customers (Belderbos, 2003; Chen \& Findlay, 2003; Deng, 2007; Deng, 2009; Li, 2007; Wang \& Boateng, 
2007), the process can be more or less difficult and expensive depending on firm-specific and country-specific (dis)advantages (Barkema, et al., 1996; Boateng \& Glaister, 2003; Luo \& Tung, 2007). The extant literature mentions the relevance of cultural distance in cross-border acquisition performance (Antia, et al., 2007; Aybar \& Ficici, 2009; Brock, 2005; He, et al., 2008; López-Duarte \& Vidal-Suárez, 2010; Malhotra, et al., 2011; Morosini, 1998; Morosini, et al., 1998; Steigner \& Sutton, 2011). Indeed, cross-border acquisitions are subject to liabilities of foreignness (Zaheer, 1995) that can hinder the realization of intended synergies (Brock, 2005). Though acquiring an existing company has the advantage of fast entry, buying a company with cultural difference and likely prospect of cultural conflict would force an acquirer to engage in cultural turnaround of the unit which are costly and time-consuming (Hofstede, 1989). This limits the returns that an acquirer can achieve from fast entry into a target's country. The organizational culture of bidders and targets is also important in determining the ease of access to new product and consumer markets. For instance, sociocultural factors such as mutual respect and trust make cross-border post-acquisition capability transfer and resource sharing easier (Birkinshaw, Bresman, \& Håkanson, 2000; Stahl \& Voigt, 2008). We argue in this paper that Chinese MNEs face higher liabilities of foreignness (or cultural disadvantages) than Indian bidders in their foreign acquisitions and thus cannot benefit from a fast entry into foreign markets as Indian companies do.

On one side, the fast entry in foreign markets is a significant motivation for cross-border acquisitions from Indian MNEs as they can benefit from an organizational culture that favors a faster access to foreign product and consumer markets. As pointed out by the Accenture Report (2006), Indian acquirers fulfill the needs to gain new markets via overseas M\&As. Moreover, Indian outward FDI involves mostly private sector firms, typically large, diversified business houses (Athreye \& Kapur, 2009; Sun, et al., 2012) which need to react quickly to increased global competition. This new market seeking is facilitated by the fact that India is a commonwealth country and has experienced a long-term influence from western countries. As a consequence of India being a former British colony, English is the official language in India, suggesting that Indian firms have higher multinational communication skills and fewer obstacles for global integration, especially with the increasing use of English in global business (Buckley, et al., 2012). Moreover, if we look at Hofstede's (1980) cultural dimensions, India has a smaller score than China on the masculinity-femininity (MAS) dimension, suggesting that India is a more feminine society than China. Feminine societies encourage the building of trust and empathy within organizations (Hofstede, 1980) and existing evidence shows that the creation of trust improves synergy realization within cross-border M\&As (Birkinshaw, et al., 2000; Stahl \& Voigt, 2008).

On the other side, Chinese MNEs face a high potential clash of culture in their cross-border acquisitions as many Chinese managers crucially lack fluent communication skills, cross-cultural knowledge, foreign management experience and fluency in English (Dietz, et al., 2008). Hence, the organizational culture of Chinese acquirers is not recognized as a factor that could ease and speed up 
the access to foreign markets. We thus suggest that Chinese acquirer's attempts at fast entry into foreign markets are not facilitated by the reality of engaging with diverse target country business environments (Hofstede, 1989).

Overall, only Indian acquirers' motivation for fast entry into foreign markets is affected by cultural distance and their shareholders recognize and value this motive. We use the cultural distance between the home and host countries as a proxy for the cultural advantage (disadvantage) of Indian (Chinese) bidders in foreign markets. Hence we expect cultural distance to significantly impact the abnormal returns of acquirers in India, i.e., shareholders react positively to acquisitions into countries having a minimal cultural difference with India, but we do not expect such effect in China.

\section{H3: Indian bidders experience more significant abnormal returns when they target countries with a small cultural distance as compared to Chinese bidders.}

\subsection{Measurement of predictor variables}

The first set of explanatory variables is related to the strategic resource hypothesis. What we are interested in is whether there is a positive relationship between the abnormal return for shareholders and the competitive advantage of Chinese (Indian) bidders. The first dummy variable, MANUFACTURING (SERVICES), takes the value of one if the Chinese (Indian) bidder's main activity is in the manufacturing (services) industry, zero otherwise. This measure captures the competitive advantage of Chinese and Indian acquirers (H1). The second dummy, DEVELOPED, takes value of one if the host country is a member of the Organization for Economic Cooperation and Development (OECD) and/or a member of the advanced economies list from the International Monetary Fund (IMF). Since the OECD and the IMF list comprise 32 and 35 (respectively) highly industrialized countries, several authors use these memberships as proxies for developed countries (Buckley, et al., 2007; Gubbi, et al., 2010). Generally, target firms in developed countries own more advanced tangible and intangible assets that can provide more core competitive advantages to bidder firms (H2).

In order to test the fast entry hypothesis (H3), we use the cultural distance between the bidder's and the target's country to measure the cultural (dis)advantage of Chinese and Indian acquirers. Cultural distance has been widely related to cross-border acquisition performance and various measures of cultural distance have been used. The most common measure is based on Hofstede's (1980) cultural dimensions, which are power distance index (PDI), individuality-collectivism (IDV), masculinity-femininity (MAS), and uncertainty avoidance index (UAI). Despite many criticisms, there is extensive evidence of the validity and reliability of Hofstede's national cultural scores (Drogendijk \& Slangen, 2006; Kogut \& Singh, 1988; Morosini \& Singh, 1994). Following previous literature (Kogut \& Singh, 1988; Morosini, et al., 1998), we calculate a composite measure of cultural distance as: 


$$
\text { CD_COMPOSITE } f=\sqrt{\sum_{i=1}^{4}\left(I_{i f}-I_{i n}\right)^{2}}
$$

where $I_{i}$ is the index for each cultural dimension, $i=\{P D I, I D V, M A S, U A I\} ; f$ denotes the foreign country and $h$ denotes the home country (either China or India). This composite index has been widely used in the international business literature (Barkema, et al., 1996; Flores \& Aguilera, 2007; Lee, Shenkar, \& Li, 2008; Loree \& Guisinger, 1995; Meschi \& Riccio, 2008; Park \& Ungson, 1997; Thomas \& Grosse, 2001; Tihanyi, Griffith, \& Russell, 2005). Although other measures of cultural distance have been suggested (Barkema, et al., 1996; Drogendijk \& Slangen, 2006; Park \& Ungson, 1997; Ronen \& Shenkar, 1985; Schwartz, 1994; Shenkar, 2001), Drogendijk and Slangen (2006) show that "it may be premature to dismiss Hofstede's work as outdated or as inaccurately reflecting national cultures". We also calculate the cultural distance between the home and host country on each individual cultural dimension, as suggested by Shenkar (2001). Following Aybar and Ficici (2009), we thus calculate $C D_{-} i_{f}$ for each dimension $i$ as: $C D_{-} i_{f}=\left|I_{i h}-I_{i f}\right|$. As emphasized in section 3.3, we expect the short-term performance of Indian cross-border acquisitions to be affected by cultural distance, especially on the MAS dimension.

\section{Data and Methodology}

\subsection{Data selection}

The data on Chinese and Indian acquisitions from January 2000 to December 2010 have been obtained from Thomson One database. We screen this database according to the following criteria: (i) the acquirer is either a Chinese company listed on Shanghai or Shenzhen Stock Exchange, or an Indian company listed on Bombay Stock Exchange; (ii) the target country is different from the bidder country; (iii) the acquirer obtains at least $50 \%$ of the shares of the target (to focus only on majoritystock acquisitions) and (iv) the transaction has been completed. In order to compute abnormal returns, we collect data on daily stock returns and daily market returns from Thomson DataStream. The joining of both Thomson One and DataStream data led to a sample which consists of 389 cross-border acquisitions, including 310 from Indian companies and 79 from Chinese bidders. For the Chinese market portfolio, we use two different indices, the Shanghai SE Composite and the Shenzhen SE Composite, depending on whether the bidder is listed on Shanghai Stock Exchange or Shenzhen Stock Exchange. For the Indian market portfolio, we use the index BSE-500 which represents the 500 largest capitalizations on the Bombay Stock Exchange. In order to collect all characteristics information for our control variables, we use both Thomson One and Thomson DataStream. ${ }^{1}$ From our sample of 389 deals, we keep only the deals for which we have available data on all our control

\footnotetext{
${ }^{1}$ We also use the China Center for Economic Research (CCER) database to control for state ownership in China.
} 
variables, which narrows our final sample down to 63 deals for China and 203 deals for India.

Moreover, both bidder and target companies are classified into industry groups based on their primary Standard Industrial Classification (SIC) code. Following previously suggested classification of such data (Ghemawat, 2001; Moeller \& Schlingemann, 2005), we classify companies into eight main industries: Primary sector (Agriculture, Fishing, Forestry and Mining), Construction, Manufacturing, Transportation, Wholesale trade, Retail trade, Financial sector (banks, insurance companies, real estate, etc.), and Services. Finally, national cultural dimensions PDI, IDV, MAS and UAI were collected for each country in our sample from Geert Hofstede's website.

\subsection{Sample description}

Table 1 summarizes our final sample of Chinese deals (Panel A) and Indian deals (Panel B). In both countries, most cross-border acquisitions involve a manufacturing bidder (51-54\%). Moreover, Indian service companies employ cross-border M\&As to expand their competitive advantage, representing one third (34\%) of all Indian deals in our sample. In China, the second biggest industry represented in cross-border transactions is the financial industry (19\%) whereas bidders from the service industry represent only $8 \%$ of Chinese deals. Regarding the target country, the U.S. has the priority for Indian acquirers, followed by the U.K., Singapore and Germany. For Chinese companies seeking cross-border M\&As to expand foreign investment, Hong Kong is the prime target region, followed by Australia, Singapore and Japan. Although both Indian and Chinese acquirers favored developed countries for their cross-border transactions (83\%-84\%), Indian acquirers seem to be more "outgoing". Three of the four top ranking target countries for Indian companies are traditional Western industrialized countries, while the top four target countries in the Chinese list are all from neighboring Asian-Pacific region. Regarding the cultural distance, English-speaking countries are more inclined to attract Indian cross-border M\&A investment, with $70 \%$ of all Indian deals. On the contrary, only $36 \%$ of Chinese deals occurred in Chinese-speaking countries, partly because only few countries and regions use Chinese as official language. Language and cultural distance are potentially a bigger problem for Chinese acquirers. One interesting and important characteristic of Chinese crossborder M\&As is that $62 \%$ of deals are conducted by state-owned acquirers, which demonstrates the importance of state-holding capital in the Chinese economy.

[Table 1 about here]

\subsection{Event study}

In order to assess the short-term performance of a particular deal, we use a standard event study methodology and compute daily abnormal returns around the acquisition announcement date. Following Brown \& Warner (1985) and Bouwman, Fuller, \& Nain (2009), we use the modified market model which defines abnormal returns (AR) for any day as the difference between the bidder return and the market return: 
$A R_{i t}=R_{i t}-R_{m t}$,

where $R_{i t}$ is the daily return on the acquirer and $R_{m t}$ is the daily return on the market. We thus consider market returns as "normal returns" for the bidder's stock, and we discuss our choice in Section 6. The event study methodology assumes that stock markets are efficient, i.e., that any new information is instantaneously incorporated in stock prices. M\&A event studies in developed markets generally use a short event window ( 3 days) around the announcement date. Since emerging markets are not as efficient (due to imperfect regulatory environment, insider trading, etc.), we use a 5-day event window to test the market response in these two emerging economies (a longer event window could dilute the announcement effect).

We thus compute the cumulative abnormal return (CAR) by summing the daily abnormal returns over a 5-day event window, running from 3 days before the announcement date to 1 day after. For each deal, the cumulative abnormal return is:

$C A R_{i}=\sum_{t=-3}^{+1} A R_{i t}$

Table 2 presents the daily average abnormal returns (AAR) and the cumulative average abnormal returns (CAAR) over the event window $(-3 ;+1)$ for Chinese and Indian deals respectively. In China (Panel A), only the AAR(-3) and AAR(-2) are significantly positive according to the t-statistic. In India (Panel B), only the AAR(0) is significantly positive. The CAAR $(-3 ;+1)$ for Chinese and Indian acquirers are both highly significant and positive. Following previous literature (Aybar \& Ficici, 2009; Bhagat, et al., 2011; Gubbi, et al., 2010), we conduct a Wilcoxon signed-rank test (WSR), also known as the Wilcoxon matched-pairs test. This is the non-parametric equivalent of the paired t-test; i.e., we test the median difference (instead of the mean difference) in paired data. This confirmatory non-parametric test is important as our data sample includes potentially significant outliers. The WSR test confirms our findings as both CAAR are highly significant (55\% of all acquirers experienced a significantly positive CAR).

[Table 2 about here]

\subsection{Cross-sectional model specifications}

In order to test our hypotheses, a series of cross-sectional regressions were estimated with cumulative abnormal returns (CAR) as dependent variables for China and India. The basic model specification consists of regressions with only control variables included as independent variables: CAR $_{\mathrm{i}}=\beta_{0}+\beta_{1}$ CASH $_{\mathrm{i}}+\beta_{2}$ RELATIVESI ZE $_{\mathrm{i}}+\beta_{3}$ PERCENTACQ $_{\mathrm{i}}+\beta_{4}$ RELATEDNES S $_{\mathrm{i}}$ $+\beta_{5}$ PRIVATE $_{\mathrm{i}}+\beta_{6}$ INDPRES $_{\mathrm{i}}+\beta_{7}$ COUNPRES $_{\mathrm{i}}+\beta_{8}$ STATE $_{\mathrm{i}}+\varepsilon_{\mathrm{i}}$

$\mathrm{CASH}_{\mathrm{i}}$ is a dummy variable equal to one if the acquisition is cash-financed, zero otherwise.

RELATIVESIZE $_{\mathrm{i}}$ is the deal value divided by the bidder's pre-acquisition market value. PERCENTACQ $_{\mathrm{i}}$ is the percentage stake acquired through the transaction. RELATEDNESS $\mathrm{i}_{\mathrm{i}}$ is 
dummy variable which equals one if the target's main industry is the same as the acquirer, zero otherwise. PRIVATE $\mathrm{i}_{\mathrm{i}}$ is a dummy variable equal to one if the target is privately held, zero otherwise. INDPRES $_{\mathrm{i}}$ and COUNPRES $\mathrm{C}_{\mathrm{i}}$ are dummy variables that account for the bidder's prior experience in acquiring a company in the same industry (country) as the current target. STATE $\mathrm{i}_{\mathrm{i}}$ is a dummy variable equal to one if the bidder is state-owned, zero otherwise. This last variable is relevant only for Chinese deals.

Once we estimated this multivariate model for Indian and Chinese deals respectively (Model 1), we ran similar regressions including alternatively each predictor variable in the model: MANUFACTURING (SERVICES) for Model 2, DEVELOPED for Model 3, and five cultural distance proxies (CD_PDI, CD_IDV, CD_MAS, CD_UAI and CD_COMPOSITE) for Models 4-8. These variables have been defined in Section 3.4. As emphasized below (and in Table 3), these predictors are significantly correlated with each other. Inputting these variables in the same regression model would result in multi-collinearity problems, which is why we use separate models to test the explanatory power of each variable.

\section{Results and Analysis}

Table 3 reports the correlations between all variables used in the analysis for Chinese deals (Panel A) and Indian deals (Panel B). It can be seen that the independent variables have significant correlations with each other, especially the five CD proxies. In China, CD_COMPOSITE is highly correlated with CD_PDI (0.79) and CD_IDV (0.86). The same pattern appears (to a lesser extent) in India. Another concern arises in the Indian sample, as DEVELOPED is highly correlated with all CD measures, except CD_MAS. This is due to the distribution of the sample, as most Indian cross-border acquisitions are targeting U.S. and U.K. companies, two developed markets with a potentially high cultural distance with India. On the IDV dimension for instance, India encounters the largest cultural distance with the U.S. (CD_IDV=43) and the U.K. (CD_IDV=41). This is consistent with previous evidence showing that individualism is statistically correlated with national wealth (Hofstede, 1994). Thus using CD_IDV or for similar reasons CD_PDI and CD_COMPOSITE in order to test H3 might conflict with the test of H2. CD_MAS is the least correlated with DEVELOPED, representing the best alternative to test for the fast entry hypothesis in India. Moreover, this measure captures the potential impact of femininity on cross-border M\&A synergies and performance (Birkinshaw, et al., 2000; Stahl \& Voigt, 2008).

\section{[Table 3 about here]}

Tables 4 and 5 summarize the regression results for Chinese deals and Indian deals respectively. Model 1 is the regression with only control variables, Model 2 includes the competitive advantage dummy (MANUFACTURING for China and SERVICES for India), Model 3 includes the dummy for acquisitions in developed markets, and Models 4-8 test for our fast entry hypothesis with alternative proxies for cultural distance. Over the eight model specifications, the control variables are usually not 
statistically significant. For China, the only exceptions are STATE (Model 2) and RELATEDNESS (Model 3). The significant coefficient for STATE is positive (at the 10\% significance level), which is consistent with the fact that investors expect state-owned companies to better succeed in exploring the benefits of cross-border M\&As (Buckley, et al., 2007; Sun, et al., 2012). In Model 3, RELATEDNESS is significantly negative (at the $10 \%$ level), which is contrary to what we expected and indicates that investors react favorably to industry diversification by Chinese companies. This result however is consistent with Buckley, et al. (2007) who argue that Chinese outward FDI are partly driven by risk aversion, and thus diversification is seen as a good way of reducing the total risk of the company. In India, COUNPRES is significantly positive and the constant is significantly negative in Model 5 . The positive coefficient for prior country presence suggests that Indian MNEs benefit from previous acquisitions in the same target country and is consistent with Slangen (2006).

[Tables 4 and 5 about here]

\subsection{Competitive advantage hypothesis}

In Table 4 Model 2, MANUFACTURING is positive and significant at the $1 \%$ level. This is aligned with the global image of "Made in China", i.e., China is well-known all around the world for its manufacturing industry due to availability of cheap labor and plentiful natural resources. Therefore, investors strongly believe that cross-border M\&As from Chinese manufacturers, in the pursuit of strategic resources (mainly natural resources), can enhance their competitive advantage and thus their long-term performance.

Similarly, Indian companies in the service industry enjoy a competitive advantage both within their borders and across borders (Accenture, 2006; Buckley, et al., 2012; Sun, et al., 2012); and investors recognize that these companies are able to further develop this advantage abroad by acquiring strategic (mainly advanced technology) resources. The SERVICES coefficient is positive and significant at the $1 \%$ level in Table 5 Model 2.

\subsection{Developed target country hypothesis}

The variable DEVELOPED in Model 3 is positive and significant at the 5\% level for both China (Table 4) and India (Table 5), indicating that acquirers from both countries gain more abnormal returns when the target firm is located in a developed country. Developed markets have more advanced tangible and intangible resources and reliable institutional regulations. Through crossborder acquisitions, companies can enjoy these advantages and thus increase the value for their shareholders (Buckley, et al., 2012). Although our sample highlighted that Indian acquirers targeted more Western Anglo-Saxon countries and Chinese companies targeted more Australasian countries, both targeted mostly developed countries (83\%-84\%). This reflects that complementary capabilities and normalized institutional environment offered by developed countries have attracted more firms from emerging economies to expand globally (Gubbi, et al., 2010; Sun, et al., 2012). 


\subsection{Fast entry and cultural distance hypothesis}

Acquiring MNEs are more likely to choose same-language and same-culture firms as targets (Grinblatt \& Keloharju, 2001). Even though Chinese acquirers primarily target neighboring AsianPacific countries (e.g. Hong Kong and Singapore), cultural distance does not play an important role in acquirers' returns. In Table 4 Models 4-8, we fail to find a statistical significance for the CD variable, calculated either on each individual cultural dimension or as a composite index. This means that the organizational culture of Chinese acquirers is not recognized by shareholders as a factor that could ease and speed up the access to foreign markets. Chinese MNEs using cross-border acquisitions as the easiest way to acquire strategic assets cannot benefit from fast entry advantages, as they face high cultural clashes when expanding abroad. Indeed Chinese managers lack communication skills, crosscultural knowledge and foreign management experience (Dietz, et al., 2008), making any cross-border acquisition (even in geographically and/or culturally close countries) even more challenging (Hofstede, 1989).

For India (Table 5 Models 4-8), cultural distance has a significant impact on bidders' returns (5\% significance) on the IDV and MAS dimensions, suggesting that culture is an important factor influencing shareholders prospective of cross-border transactions. As shown in Table 3, CD_IDV and CD_MAS are negatively correlated in India (-0.36), hence the opposite sign between both coefficients (positive for IDV and negative for MAS) was expected. However we have also emphasized at the beginning of section 5 that all CD measures (except CD_MAS) are highly correlated with the variable DEVELOPED (H2). Thus the CD_IDV variable may be interpreted as another measure of the economic development of the target country (as India faces the largest IDV distance with developed countries such as U.S. and U.K.), and the significance of the coefficient in Model 5 is consistent with our result for H2 (Model 3). As suggested earlier, CD_MAS is our best proxy for testing H3, and the coefficient is consistent with our fast entry hypothesis. The negative sign implies that Indian bidders earn higher returns when targeting culturally close countries. India enjoys the advantage of being a commonwealth country with a long-term influence from western countries as well as having high multinational communication skills (Buckley, et al., 2012). When both the bidder and the target companies share a common culture (e.g. the same language), the international transaction has less obstacles and more chance of rapid success (Buckley, et al., 2012). Moreover, India is characterized as a feminine society (small MAS score), and when targeting other feminine countries (with a small cultural distance on MAS), bidders are able to further improve the realization of M\&A synergies (Birkinshaw, et al., 2000; Stahl \& Voigt, 2008). Thus shareholders recognize the cultural advantage of Indian MNEs as an accelerating factor in the race for accessing new markets and strategic assets.

Finally, in order to compare the impact of cultural distance on the performance of Chinese and Indian acquirers, we perform a z-test for the difference in regression coefficients, consistent with previous empirical studies in international business (Danis, De Clercq, \& Petricevic, 2011). In support of H3, the CD_COMPOSITE coefficient is significantly higher for India than for China (z-value = 
12.60). Similarly, the z-value is strongly significant for the CD_IDV (19.88) and CD_MAS (-13.20) components. These results are consistent with the fact that Chinese companies, because of higher liabilities of foreignness, cannot benefit from a fast entry into foreign markets as Indian companies do.

Overall, our regression results are consistent with our hypotheses. Regarding H1, both Chinese and Indian acquirers create significant abnormal returns when they expand their competitive advantage abroad. With respect to $\mathrm{H} 2$, both countries tend to acquire target firms in more developed economies and produce higher cumulative abnormal returns. These results suggest that strategic resource seeking is an important motivation for cross-border acquisitions from both Chinese and Indian bidders, although they target different kinds of strategic resources - Chinese acquirers are more interested in natural resources whereas Indian companies are seeking more advanced resources (e.g. technological). Comparatively, Indian bidders significantly benefit from a fast entry into culturally close countries, especially in countries sharing a feminine organizational orientation (characterized by trust and mutual respect).

\section{Conclusion and discussion}

With the remarkable economic achievements made by China and India in the recent decades, MNEs from these two fast-growing economies have been playing an increasingly important role in the world's M\&A activity. Aligned with this trend, issues such as the performance, motivation and other facets of international acquisitions from EM companies are gaining interest in the academic literature, although remaining at an early stage. Our research enriches the extant literature by formally testing different motives for cross-border acquisitions and examining their impact on the bidder's performance, as well as comparing between two emerging markets: China and India.

We hypothesize that traditional motives for cross-border deals that have been emphasized in the context of developed-market acquirers are not all relevant in the case of bidding companies from emerging markets. Moreover, we argue that companies located in different emerging countries (e.g. China and India) will have different motivations to expand abroad, based on specific characteristics of the home country as well as its relatedness to the target country. The two main motivations for EM firms acquiring foreign targets are strategic resource seeking and fast entry to foreign markets. On one side, strategic resource seeking is an important motivation for cross-border acquisitions from both Chinese and Indian bidders. However, Chinese companies are more interested in securing natural resources and acquiring superior managerial skills (Accenture, 2006; Dietz, et al., 2008; Sun, et al., 2012); whereas Indian companies are seeking more advanced resources such as leading technologies and knowledge-based abilities (Buckley, et al., 2012). On the other side, the fast entry to foreign markets is a key motive for Indian acquirers who use foreign acquisitions to fulfill their need to rapidly gain new markets (Accenture Report, 2006). As a consequence of India being a former British colony and a more feminine society, Indian firms have higher multinational communication skills, fewer obstacles for global integration and easier access to new product and client markets. Thus 
Indian companies enjoy a cultural advantage when targeting foreign markets, especially developed economies and countries sharing a feminine culture in the organization. This fast entry hypothesis is not a relevant motivation for Chinese bidders who face a high potential clash of culture when acquiring foreign companies. Indeed many Chinese managers crucially lack fluent communication skills, cross-cultural knowledge, foreign management experience and fluency in English (Dietz, et al., 2008).

Using a sample of cross-border acquisitions from China (63 deals) and India (203 deals) over the period 2000-2010, we investigate these motives by examining the short-term reaction of the bidder's shareholders around the deal announcement date, following a standard event study methodology combined with a multivariate regression analysis. Our results support our hypotheses and can be summarized as follows. In the preliminary univariate analysis, we find a significant cross-border effect, i.e., acquiring firms from both countries earn abnormal returns when they announce a crossborder transaction. This is consistent with previous findings of a cross-border effect in Indian acquisitions (Gubbi, et al., 2010). We explain these abnormal returns in our cross-sectional analysis by testing for three alternative hypotheses and controlling for various deal and bidder characteristics. First, shareholders of bidding companies in both China and India recognize the competitive advantage these firms enjoy in their respective industry and the motive for expanding this competitive advantage abroad. Chinese firms have a competitive advantage in the manufacturing industry and we find that manufacturing companies earn a significant premium of $3.8 \%$ (equivalent to $15 \%$ monthly) in their cross-border acquisitions. Similarly, Indian companies that operate in the service industry earn a positive abnormal return of $2.5 \%$ (about $10 \%$ monthly) when expanding their competitive advantage across their borders. The great achievements and rapid growth of developing-country MNEs in the recent years have given their shareholders more confidence to their business success when these companies seek cross-border M\&As for strategic expansions. Second, cross-border deals targeting developed countries create value for both Chinese and Indian investors. This value creation amounts $5.4 \%$ for Chinese bidders and 2.2\% for Indian companies. This result is consistent with EM companies using cross-border M\&As to pursue better resources, larger market access and stronger competitive advantage. As Gubbi, et al. (2010) have pointed out, developed countries have better quality of resources and institutions, leading to stronger synergies of the acquisition deals. Finally, we demonstrate the importance of minimal cultural distance as a fast entry mode for Indian acquirers. Using different proxies of cultural distance, we find that Indian acquirers generate additional value when targeting culturally close markets, especially countries with a minimal distance on the masculinity-femininity index (Hofstede, 1980). This result uncovers the importance of organizational culture for business success. Cultural closeness, especially in feminine societies characterized by mutual respect and trust, is essential in the process of business integration, even more when a crossborder acquisition has been chosen as the fastest mode of entry into foreign markets. Consistent with 
our hypothesis, Chinese acquirers have a cultural disadvantage in foreign markets and do not benefit from targeting countries with a similar culture.

Our paper is not without some limitations, summarized below along with some suggestions for future areas of research. First, our sample of Chinese cross-border deals is still very limited. From an original list of 256 completed cross-border M\&A deals undertaken by listed Chinese acquirers over the period 2000-2010 (from Thomson One), we were able to match only 63 acquisition deals with DataStream - after applying the criteria that acquirers are listed on either Shenzhen or Shanghai Stock Exchange, with full characteristics information. ${ }^{2}$ The criterion to retain only publicly listed companies with daily stock market data available around the announcement date is necessary to apply the event study methodology. We thus acknowledge that our results might not hold for private companies who might have different motivations for acquisitions, especially foreign acquisitions.

Moreover, by analyzing the short-term reaction of shareholders, we do not make any predictions about the long-term performance of these cross-border acquisitions. A positive short-term performance does not necessarily imply the long-term success of the international business integration. The idea of our paper was to investigate how shareholders recognize and value the intrinsic motives behind foreign M\&A investments. Future research can be to examine the motivations of private companies from emerging markets to expand abroad and/or analyze the long-term performance of these international M\&As. As Chinese MNEs are increasingly part of the global M\&A activity, future research will naturally enjoy a more comprehensive field of study in this area. Second, the modified market model used in this article to calculate abnormal returns is one among others, and we recognize that using market returns as "normal returns" might seem simplistic. Several models have been used to compute bidders' abnormal returns, the most common being the market model which estimates normal returns for the bidder over a period of few months before the event (Brown \& Warner, 1985). However, as our sample includes several consecutive deals (i.e., the same company announcing different acquisitions within the same couple of months), we would lose a significant number of deals by using the market model (as any estimation period including another announcement cannot be considered as "normal"). In order to include as many transactions as possible in our analysis, we use the modified market model to compute abnormal returns which has also been used in other event studies (Bouwman, et al., 2009; Brown \& Warner, 1985). Moreover, Brown and Warner (1985) do no find any evidence that one model performs better than the other; they even show that more complicated methodologies can make the analysis worse of. Future research into emerging-country M\&As might develop a more appropriate model taking into account the specificities of stock markets in these countries. The choice

\footnotetext{
${ }^{2}$ As our sample includes nearly four times more Indian deals than Chinese deals, we also carried out a matchedsample analysis of CAAR. The matched sample is designed according to the following criteria. First, we find the deals that occurred in the same announcement period, i.e. one year range around the announcement date. Second, we match remaining deals within the same bidder industry. Last, deals are gathered from the smallest difference in the market value of both bidding firms. In this case, the CAAR for both countries is still positive (significant only for China).
} 
of the event window, with regard to the efficiency of the stock market, is an example of an empirical issue that still needs to be explored.

To summarize, our study contributes to the extant growing literature focusing on EM firms expanding across their borders by acquiring foreign companies, mainly in more developed countries. We have evidenced that strategic resource seeking and fast entry to foreign markets are rational motives for choosing M\&As as a mean of internationalization, and that shareholders recognize and value such motives. EM companies enjoying a strong competitive advantage in their industry and country can easily expand this advantage abroad by acquiring foreign targets. Cross-border M\&A activity, as the main mode of internationalization from EM firms, still needs more in-depth and advanced studies in order to offer a comprehensive understanding of the motives and performance of such events. 


\section{References}

Accenture. (2006). India goes global: How cross-border acquisitions are powering growth. http://www.accenture.co.za/SiteCollectionDocuments/PDF/India_goes_global.pdf, accessed on 15 June 2011.

Akbulut, M. E., \& Matsusaka, J. G. (2010). 50+ years of diversification announcements. Financial Review, 45, 231-262.

Antia, M., Lin, J. B., \& Pantzalis, C. (2007). Cultural distance and valuation of multinational corporations. Journal of Multinational Financial Management, 17, 365-383.

Arora, A., Arunachalam, V. S., Asundi, J., \& Fernandes, R. (2001). The Indian software services industry. Research Policy, 30, 1267-1287.

Athreye, S., \& Kapur, S. (2009). Introduction: The internationalization of Chinese and Indian firms-trends, motivations and strategy. Industrial \& Corporate Change, 18, 209-221.

Aulakh, P., Kotabe, M., \& Teegen, H. (2000). Export strategies and performance of firms from emerging economies: Evidence from Brazil, Chile, and Mexico. Academy of Management Journal, 43, 342-361.

Aybar, B., \& Ficici, A. (2009). Cross-border acquisitions and firm value: An analysis of emergingmarket multinationals. Journal of International Business Studies, 40, 1317-1338.

Barkema, H. G., Bell, J. H. J., \& Pennings, J. (1996). Foreign entry, cultural barriers and learning. Strategic Management Journal, 17, 151-166.

Barney, J. (1991). Firm resources and sustained competitive advantage. Journal of management, 17, 99.

Belderbos, R. (2003). Entry mode, organizational learning, and R\&D in foreign affiliates: evidence from Japanese firms. Strategic Management Journal, 24, 235-259.

Bertrand, O., \& Zitouna, H. (2008). Domestic versus cross-border acquisitions: which impact on the target firms' performance? Applied Economics, 40, 2221-2238.

Bhagat, S., Malhotra, S., \& Zhu, P. C. (2011). Emerging country cross-border acquisitions: Characteristics, acquirer returns and cross-sectional determinants. Emerging Markets Review, 12, 250-271.

Birkinshaw, J., Bresman, H., \& Håkanson, L. (2000). Managing the Post - acquisition Integration Process: How the Human Iintegration and Task Integration Processes Interact to Foster Value Creation. Journal of Management Studies, 37, 395-425.

Blackburn, V. L., Dark, F. H., \& Hanson, R. C. (1997). Mergers, Method of Payment and Returns to Manager- and Owner-Controlled Firms. Financial Review, 32, 569-589.

Boateng, A., \& Glaister, K. W. (2003). Strategic motives for international joint venture formation in Ghana. Management International Review, 43, 107-128.

Boateng, A., Qian, W., \& Tianle, Y. (2008). Cross-border M\&As by Chinese firms: An analysis of strategic motives and performance. Thunderbird international business review, 50, 259-270.

Boddewyn, J. J., Halbrich, M. B., \& Perry, A. C. (1986). Service multinationals: conceptualization, measurement and theory. Journal of International Business Studies, 17, 41-57.

Bouwman, C., Fuller, K., \& Nain, A. (2009). Market valuation and acquisition quality: Empirical evidence. Review of Financial Studies, 22, 633.

Bowen, D. E., \& Jones, G. R. (1986). Transaction cost analysis of service organization-customer exchange. Academy of Management Review, 11, 428-441.

Brock, D. M. (2005). Multinational acquisition integration: the role of national culture in creating synergies. International Business Review, 14, 269-288.

Brown, D. T., \& Ryngaert, M. D. (1991). The mode of acquisition in takeovers: Taxes and asymmetric information. Journal of Finance, 46, 653-669. 
Brown, S., \& Warner, J. (1985). Using daily stock returns: The case of event studies. Journal of financial economics, 14, 3-31.

Buckley, P. J., Clegg, L. J., Cross, A. R., Liu, X., Voss, H., \& Zheng, P. (2007). The Determinants of Chinese Outward Foreign Direct Investment. Journal of International Business Studies, 38, 499-518.

Buckley, P. J., Forsans, N., \& Munjal, S. (2012). Host-home country linkages and host-home country specific advantages as determinants of foreign acquisitions by Indian firms. International Business Review, 21, 878-890.

Cai, K. G. (1999). Outward foreign direct investment: A novel dimension of China's integration into the regional and global economy. China Quarterly, 160, 856-880.

Cakici, N., Hessel, C., \& Tandon, K. (1996). Foreign acquisitions in the United States: Effect on shareholder wealth of foreign acquiring firms. Journal of Banking \& Finance, 20, 307-329.

Capron, L., \& Shen, J. C. (2007). Acquisitions of private vs. public firms: Private information, target selection, and acquirer returns. Strategic Management Journal, 28, 891-911.

Chan, C. M., Isobe, T., \& Makino, S. (2008). Which country matters? Institutional development and foreign affiliate performance. Strategic Management Journal, 29, 1179-1205.

Chari, A., Ouimet, P., \& Tesar, L. (2004). Cross Border Mergers and Acquisitions in Emerging Markets: The Stock Market Valuation of Corporate Control. In EFA 2004 Maastricht.

Chen, C., \& Findlay, C. (2003). A Review of Cross-border Mergers and Acquisitions in APEC. AsianPacific Economic Literature, 17, 14-38.

Chen, S. F. S. (2008). The motives for international acquisitions: capability procurements, strategic considerations, and the role of ownership structures. Journal of International Business Studies, 39, 454-471.

Chen, Y. Y., \& Young, M. N. (2010). Cross-border mergers and acquisitions by Chinese listed companies: A principal-principal perspective. Asia Pacific Journal of Management, 27, 523539.

Chittoor, R., \& Ray, S. (2007). Internationalization paths of Indian pharmaceutical firms--A strategic group analysis. Journal of international management, 13, 338-355.

Choi, J., \& Russell, J. S. (2004). Economic gains around mergers and acquisitions in the construction industry of the United States of America. Canadian Journal of Civil Engineering, 31, 513525.

Cui, L., \& Jiang, F. (2010). Behind ownership decision of Chinese outward FDI: Resources and institutions. Asia Pacific Journal of Management, 27, 751-774.

Danis, W. M., De Clercq, D., \& Petricevic, O. (2011). Are social networks more important for new business activity in emerging than developed economies? An empirical extension. International Business Review, 20, 394-408.

Deng, P. (2007). Investing for strategic resources and its rationale: The case of outward FDI from Chinese companies. Business Horizons, 50, 71-81.

Deng, P. (2009). Why do Chinese firms tend to acquire strategic assets in international expansion? Journal of World Business, 44, 74-84.

Denis, D., Denis, D., \& Yost, K. (2002). Global diversification, industrial diversification, and firm value. The Journal of Finance, 57, 1951-1979.

Dietz, M. C., Orr, G., \& Xing, J. (2008). How Chinese companies can succeed abroad. McKinsey Quarterly, 3, 22.

Doukas, J., \& Travlos, N. G. (1988). The effect of corporate multinationalism on shareholders' wealth: Evidence from international acquisitions. Journal of Finance, 43, 1161-1175. 
Drogendijk, R., \& Slangen, A. (2006). Hofstede, Schwartz, or managerial perceptions? The effects of different cultural distance measures on establishment mode choices by multinational enterprises. International Business Review, 15, 361-380.

Dunning, J. H. (1980). Towards an eclectic theory of international production: some empirical tests. Journal of International Business Studies, 11, 9-31.

Dunning, J. H. (1988). The eclectic paradigm of international production: a restatement and some possible extensions. Journal of International Business Studies, 19, 1-31.

Dunning, J. H. (1993). Multinational Enterprises and the Global Economy: Wokingham: AddisonWesley.

Dunning, J. H. (1998). Globalization, trade and foreign direct investment: Amsterdam: Elsevier.

Dunning, J. H. (2001). The eclectic (OLI) paradigm of international production: past, present and future. International Journal of the Economics of Business, 8, 173-190.

Dunning, J. H. (2006). Comment on Dragon multinationals: New players in 21 st century globalization. Asia Pacific Journal of Management, 23, 139-141.

Dunning, J. H., \& Lundan, S. M. (2008). Institutions and the OLI paradigm of the multinational enterprise. Asia-Pacific Journal of Management, 25, 573-593.

Erramilli, M. K., \& Rao, C. P. (1993). Service firms' international entry-mode choice: A modified transaction-cost analysis approach. The Journal of Marketing, 57, 19-38.

Ethiraj, S. K., Kale, P., Krishnan, M. S., \& Singh, J. V. (2005). Where do capabilities come from and how do they matter? A study in the software services industry. Strategic Management Journal, 26, 25-45.

Faccio, M., \& Masulis, R. W. (2005). The choice of payment method in European mergers and acquisitions. The Journal of Finance, 60, 1345-1388.

Flores, R. G., \& Aguilera, R. V. (2007). Globalization and location choice: an analysis of US multinational firms in 1980 and 2000. Journal of International Business Studies, 38, 11871210.

Fortanier, F., \& Tulder, R. (2009). Internationalization trajectories--a cross-country comparison: Are large Chinese and Indian companies different? Industrial and Corporate Change, 18, 223247.

Fuller, K., Netter, J., \& Stegemoller, M. (2002). What do returns to acquiring firms tell us? Evidence from firms that make many acquisitions. The Journal of Finance, 57, 1763-1793.

Ghemawat, P. (2001). Distance still matters. Harvard Business Review, 79, 137-147.

Gregory, A., \& McCorriston, S. (2005). Foreign acquisitions by UK limited companies: Short-and long-run performance. Journal of Empirical Finance, 12, 99-125.

Grinblatt, M., \& Keloharju, M. (2001). How distance, language, and culture influence stockholdings and trades. The Journal of Finance, 56, 1053-1073.

Gubbi, S., Aulakh, P., Ray, S., Sarkar, M., \& Chittoor, R. (2010). Do international acquisitions by emerging-economy firms create shareholder value: The case of Indian firms. Journal of International Business Studies, 41, 397-418.

Guillen, M. F. (2000). Business groups in emerging economies: A resource-based view. Academy of Management Journal, 43, 362-380.

Harrison, J. S., Hitt, M. A., Hoskisson, R. E., \& Ireland, R. D. (2001). Resource complementarity in business combinations: Extending the logic to organizational alliances. Journal of management, 27, 679-690.

He, F., Bin, F., \& Chen, D. H. (2008). Cross-Border M\&A: Cultural Disparities and the Associated Wealth Effects. International Journal of Business and Economics, 7, 89-1000.

Hennart, J. F. (1989). Can the "new forms of investment" substitute for the "old forms?" A transaction costs perspective. Journal of International Business Studies, 20, 211-234. 
Hofstede, G. (1980). Culture's consequences, international differences in work-related values (Vol. 5) London: Sage Publications, Inc.

Hofstede, G. (1989). Organising for cultural diversity. European Management Journal, 7, 390-397.

Hofstede, G. (1994). The business of international business is culture. International Business Review, $3,1-14$.

Jensen, M. C. (1986). Agency costs of free cash flow, corporate finance, and takeovers. The American Economic Review, 76, 323-329.

Khanna, T., \& Palepu, K. (2000). Is group affiliation profitable in emerging markets? An analysis of diversified Indian business groups. Journal of Finance, 55, 867-891.

Khanna, T., \& Palepu, K. (2006). Emerging giants: Building world-class companies in developing countries. Harvard Business Review, 84, 60-69.

Kim, J. Y., Haleblian, J., \& Finkelstein, S. (2011). When Firms Are Desperate to Grow via Acquisition: The Effect of Growth Patterns and Acquisition Experience on Acquisition Premiums. Administrative science quarterly, 56, 26-60.

King, D. R., Dalton, D. R., Daily, C. M., \& Covin, J. G. (2004). Meta - analyses of post - acquisition performance: Indications of unidentified moderators. Strategic Management Journal, 25, 187200.

Klossek, A., Linke, B. M., \& Nippa, M. (2012). Chinese enterprises in Germany: Establishment modes and strategies to mitigate the liability of foreignness. Journal of World Business, 47, 35-44.

Kobrin, S. J. (1979). Political risk: A review and reconsideration. Journal of International Business Studies, 10, 67-80.

Kogut, B., \& Singh, H. (1988). The effect of national culture on the choice of entry mode. Journal of International Business Studies, 19, 411-432.

Kostova, T., Roth, K., \& Dacin, M. T. (2008). Note: Institutional Theory in the Study of Multinational Corporations: A Critique and new Directions. The Academy of Management Review (AMR), 33, 994-1006.

Kumar, N. (2009). How emerging giants are rewriting the rules of M\&A. Harvard Business Review, $87,115-121$.

Lamacchia, T. F. (1997). Cross-border M\&A: A guide to global strategic direct investment for Asian companies. Hong Kong: Asia Law \& Practice Publishing.

Lee, S. H., Shenkar, O., \& Li, J. (2008). Cultural distance, investment flow, and control in cross border cooperation. Strategic Management Journal, 29, 1117-1125.

Li, P. P. (2007). Toward an integrated theory of multinational evolution: The evidence of Chinese multinational enterprises as latecomers. Journal of international management, 13, 296-318.

López-Duarte, C., \& Vidal-Suárez, M. M. (2010). External uncertainty and entry mode choice: Cultural distance, political risk and language diversity. International Business Review, 19, 575-588.

Loree, D. W., \& Guisinger, S. E. (1995). Policy and non-policy determinants of US equity foreign direct investment. Journal of International Business Studies, 26, 281-299.

Lubatkin, M., \& Chatterjee, S. (1991). The strategy shareholder value relationship: Testing temporal stability across market cycles. Strategic Management Journal, 12, 251-270.

Luo, Y., \& Tung, R. L. (2007). International expansion of emerging market enterprises: A springboard perspective. Journal of International Business Studies, 38, 481-498.

Luo, Y., Xue, Q., \& Han, B. (2010). How emerging market governments promote outward FDI: Experience from China. Journal of World Business, 45, 68-79. 
Malhotra, S., Sivakumar, K., \& Zhu, P. C. (2011). A comparative analysis of the role of national culture on foreign market acquisitions by US firms and firms from emerging countries. Journal of Business Research, 64, 714-722.

Mann, B. J. S., \& Kohli, R. (2009). Impact of Mode of Payment and Insider Ownership on Target and Acquirer's Announcement Returns in India. Vikalpa, 34, 51.

Marinova, S., Child, J., \& Marinov, M. (2011). Evolution of Firm-and Country-Specific Advantages and Disadvantages in the Process of Chinese Firm Internationalization. In Dynamics of Globalization: Location-Specific Advantages Or Liabilities of Foreignness? (Vol. 24, pp. 235) Bingley: Emerald Group Publishing.

Martynova, M., \& Renneboog, L. (2008). A century of corporate takeovers: What have we learned and where do we stand? Journal of Banking \& Finance, 32, 2148-2177.

Mathews, J. A. (2006). Dragon multinationals: New players in 21 st century globalization. Asia Pacific Journal of Management, 23, 5-27.

Meschi, P. X., \& Riccio, E. L. (2008). Country risk, national cultural differences between partners and survival of international joint ventures in Brazil. International Business Review, 17, 250-266.

Miozzo, M., \& Grimshaw, D. (2008). Service multinationals and forward linkages with client firms: The case of IT outsourcing in Argentina and Brazil. International Business Review, 17, 8-27.

Moeller, S. B., \& Schlingemann, F. P. (2005). Global diversification and bidder gains: A comparison between cross-border and domestic acquisitions. Journal of Banking \& Finance, 29, 533-564.

Morosini, P. (1998). Managing cultural differences: Effective strategy and execution across cultures in global corporate alliances. Oxford and New York, NY: Pergamon.

Morosini, P., Shane, S., \& Singh, H. (1998). National cultural distance and cross-border acquisition performance. Journal of International Business Studies, 29, 137-158.

Morosini, P., \& Singh, H. (1994). Post-cross-border acquisitions: Implementing 'national culturecompatible'strategies to improve performance. European Management Journal, 12, 390-400.

Mulherin, J. H., \& Boone, A. L. (2000). Comparing acquisitions and divestitures. Journal of Corporate Finance, 6, 117-139.

Myers, S. C., \& Majluf, N. S. (1984). Corporate financing and investment decisions when firms have information that investors do not have. Journal of financial economics, 13, 187-221.

Nayyar, D. (2008). The internationalization of firms from India: investment, mergers and acquisitions. Oxford Development Studies, 36, 111-131.

Park, S. H., \& Ungson, G. R. (1997). The effect of national culture, organizational complementarity, and economic motivation on joint venture dissolution. Academy of Management Journal, 40, 279-307.

Ronen, S., \& Shenkar, O. (1985). Clustering countries on attitudinal dimensions: A review and synthesis. Academy of Management Review, 10, 435-454.

Rui, H., \& Yip, G. S. (2008). Foreign acquisitions by Chinese firms: A strategic intent perspective. Journal of World Business, 43, 213-226.

Schwartz, S. H. (1994). Beyond individualism/collectivism: new cultural dimensions of values. In U. Kim, H. C. Triandis, C. Kagitcibasi, S. C. Choi \& G. Yoon (Eds.), Individualism and Collectivism Theory Method and Applications (Vol. 18, pp. 85-119).

Shenkar, O. (2001). Cultural distance revisited: Towards a more rigorous conceptualization and measurement of cultural differences. Journal of International Business Studies, 32, 519-535.

Singh, D. A. (2009). Export performance of emerging market firms. International Business Review, 18, 321-330.

Slangen, A. H. L. (2006). National cultural distance and initial foreign acquisition performance: The moderating effect of integration. Journal of World Business, 41, 161-170. 
Smith, R. L., \& Kim, J. H. (1994). The combined effects of free cash flow and financial slack on bidder and target stock returns. Journal of business, 67, 281-310.

Stahl, G. K., \& Voigt, A. (2008). Do cultural differences matter in mergers and acquisitions? A tentative model and examination. Organization science, 19, 160.

Steigner, T., \& Sutton, N. K. (2011). How Does National Culture Impact Internalization Benefits in Cross - Border Mergers and Acquisitions? Financial Review, 46, 103-125.

Sun, S. L., Peng, M. W., Ren, B., \& Yan, D. (2012). A comparative ownership advantage framework for cross-border M\&As: The rise of Chinese and Indian MNEs. Journal of World Business, 47, 4-16.

Thomas, D. E., \& Grosse, R. (2001). Country-of-origin determinants of foreign direct investment in an emerging market: the case of Mexico. Journal of international management, 7, 59-79.

Tihanyi, L., Griffith, D. A., \& Russell, C. J. (2005). The effect of cultural distance on entry mode choice, international diversification, and MNE performance: A meta-analysis. Journal of International Business Studies, 36, 270-283.

Tsang, E. W. K., Yip, P. S. L., \& Toh, M. H. (2008). The impact of R\&D on value added for domestic and foreign firms in a newly industrialized economy. International Business Review, 17, 423441.

UNCTAD. (2006). World Investment Report: FDI from Developing and Transition Economies: Implications for Development. In UN (Ed.), United Nations Conference on Trade and Development (UNCTAD). New York \& Geneva.

UNCTAD. (2009). World Investment Report: Transnational Corporations, Agricultural Production and Development. In UN (Ed.), United Nations Conference on Trade and Development (UNCTAD). New York \& Geneva.

UNCTAD. (2010). World investment report 2010: Investing in a low-carbon economy. In UN (Ed.), United Nations Conference on Trade and Development (UNCTAD). New York \& Geneva.

UNCTAD. (2011). World Investment Report. In. http://www.unctad.org/Templates/Page.asp?intItemID=1465.

von Eije, H., \& Wiegerinck, H. (2010). Shareholders' reactions to announcements of acquisitions of private firms: Do target and bidder markets make a difference? International Business Review, 19, 360-377.

Wang, C., Hong, J., Kafouros, M., \& Boateng, A. (2012). What drives outward FDI of Chinese firms? Testing the explanatory power of three theoretical frameworks. International Business Review, 21, 425-438.

Wang, Q., \& Boateng, A. (2007). Cross-border M\&As by Chinese firms: an analysis of strategic motivation and performance. International Management Review, 3, 19-29.

Witt, M. A., \& Lewin, A. Y. (2007). Outward foreign direct investment as escape response to home country institutional constraints. Journal of International Business Studies, 38, 579-594.

Yook, K. C. (2003). Larger return to cash acquisitions: Signaling effect or leverage effect? Journal of business, 76, 477-498.

Zaheer, S. (1995). Overcoming the liability of foreignness. Academy of Management Journal, 38, 341-363.

Zeithaml, V. A., Parasuraman, A., \& Berry, L. L. (1985). Problems and strategies in services marketing. The Journal of Marketing, 49, 33-46.

Zhang, J., Zhou, C., \& Ebbers, H. (2011). Completion of Chinese overseas acquisitions: Institutional perspectives and evidence. International Business Review, 20, 226-238. 
Table 1: Regression sample description

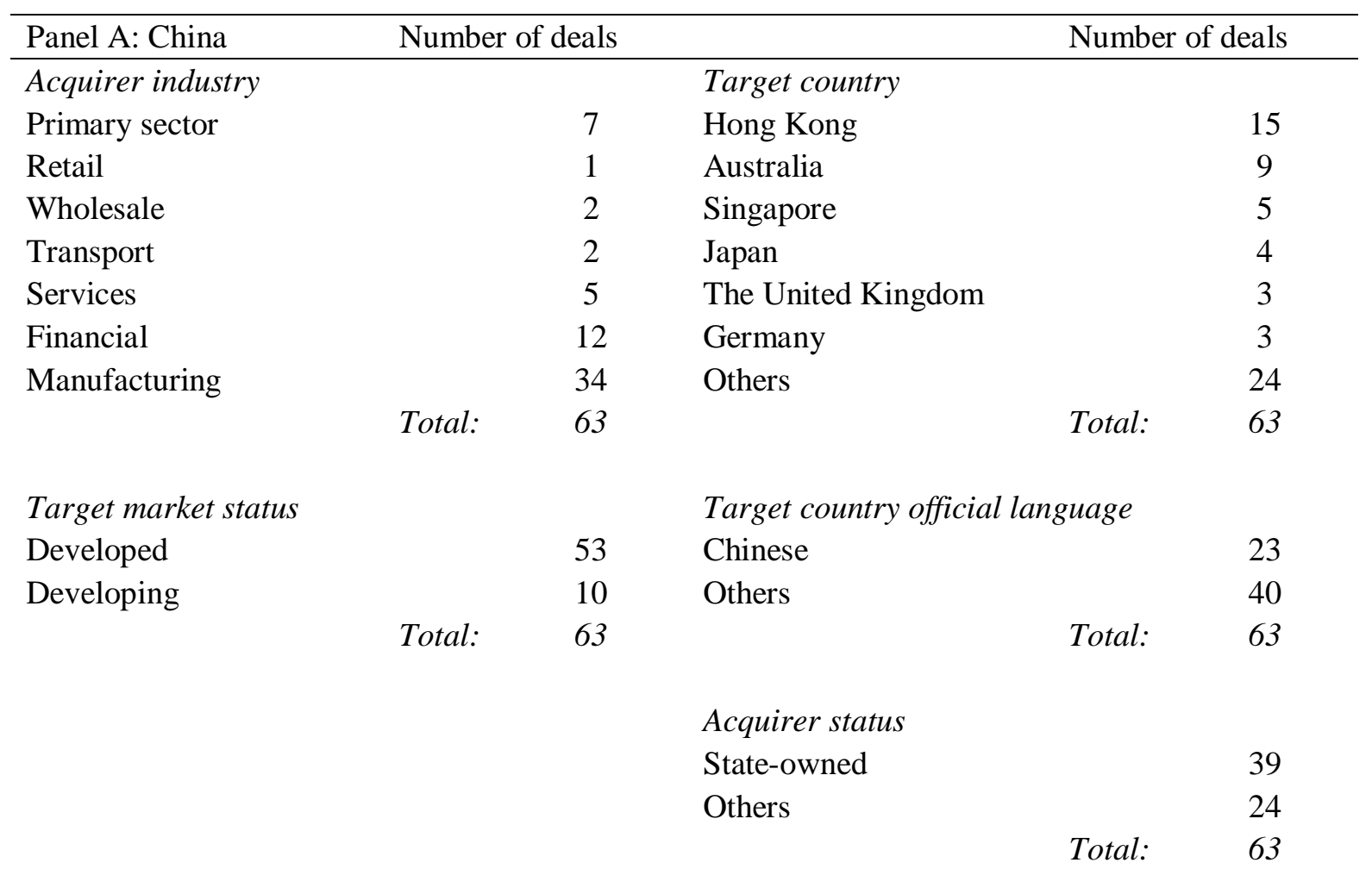

\begin{tabular}{|c|c|c|c|c|c|}
\hline \multirow{2}{*}{$\begin{array}{l}\text { Panel B: India } \\
\text { Acquirer industry }\end{array}$} & \multicolumn{2}{|c|}{ Number of deals } & & \multicolumn{2}{|c|}{ Number of deals } \\
\hline & & & Target country & & \\
\hline Primary sector & & 7 & The United States & & 65 \\
\hline Construction & & 7 & The United Kingdom & & 29 \\
\hline Wholesale & & 3 & Singapore & & 12 \\
\hline Transport & & 7 & Germany & & 11 \\
\hline Financial & & 6 & France & & 9 \\
\hline Services & & 69 & South Africa & & 8 \\
\hline \multirow[t]{2}{*}{ Manufacturing } & & 104 & Others & & 69 \\
\hline & Total: & 203 & & Total: & 203 \\
\hline Target market status & & & Target country officia & guage & \\
\hline Developed & & 168 & English & & 141 \\
\hline \multirow[t]{2}{*}{ Developing } & & 35 & Others & & 62 \\
\hline & Total: & 203 & & Total: & 203 \\
\hline
\end{tabular}


Table 2: Average abnormal returns (AAR) and cumulative average abnormal returns (CAAR)

\begin{tabular}{lcrrlccl}
\hline \multicolumn{2}{l}{ Panel A: China $(\mathrm{n}=79)$} & & & & & & \\
& Mean & Median & \multicolumn{1}{c}{ s.d. } & t-stat & positive:negative & \%positive & WSR test \\
\hline AAR(-3) & 0.0068 & 0.0034 & 0.028 & $2.15^{* *}$ & $42: 34$ & $53.16 \%$ & $1.75^{*}$ \\
AAR(-2) & 0.0059 & -0.0011 & 0.027 & $1.90^{*}$ & $35: 42$ & $44.30 \%$ & 0.70 \\
AAR(-1) & 0.0038 & 0.0011 & 0.025 & 1.31 & $41: 37$ & $51.90 \%$ & 0.73 \\
AAR(0) & 0.0023 & 0.0000 & 0.028 & 0.82 & $38: 38$ & $48.10 \%$ & 0.25 \\
AAR(+1) & 0.0031 & 0.0000 & 0.021 & 1.30 & $38: 38$ & $48.10 \%$ & 0.52 \\
& & & & & & & \\
CAAR(-3;+1) & 0.0219 & 0.0178 & 0.054 & $3.57^{* * *}$ & $44: 34$ & $55.70 \%$ & $3.24 * * *$
\end{tabular}

\begin{tabular}{lrrrlcll}
\hline \multicolumn{2}{l}{ Panel B: India $(\mathrm{n}=310)$} & & & & & & \\
& Mean & Median & s.d. & t-stat & positive:negative & $\%$ positive & WSR test \\
\hline AAR(-3) & -0.0002 & -0.0022 & 0.024 & -0.13 & $139: 170$ & $45.84 \%$ & 1.14 \\
AAR(-2) & 0.0019 & 0.0004 & 0.028 & 1.19 & $157: 153$ & $50.65 \%$ & 0.80 \\
AAR(-1) & 0.0001 & -0.0027 & 0.168 & 0.07 & $143: 166$ & $46.10 \%$ & 0.93 \\
AAR(0) & 0.0100 & 0.0053 & 0.037 & $4.67 * * *$ & $179: 131$ & $57.74 \%$ & $4.39 * * *$ \\
AAR(+1) & 0.0003 & 0.0002 & 0.028 & 0.20 & $156: 154$ & $50.32 \%$ & 0.17 \\
& & & & & & & \\
CAAR(-3;+1) & 0.0122 & 0.0056 & 0.061 & $3.50^{* * *}$ & $172: 138$ & $55.48 \%$ & $2.84 * * *$ \\
& & & & & & & \\
\hline
\end{tabular}

The table gives daily AARs over the event window as well as CAARs as the average of CAR(-3;+1) for each country. The sample is larger than in Table 1 as it includes all cross-border deals for which stock market data is available over the event window. s.d. denotes the standard deviation. One sample t-test statistics for significance of AAR and CAAR are calculated. WSR is the Wilcoxon signed-rank test, which tests for the significance of positive or negative market movement. *,**,** denote significance at $10 \%, 5 \%$ and $1 \%$ level. 
Table 3: Variables' correlation matrices

Panel A: China

\begin{tabular}{|c|c|c|c|c|c|c|c|c|c|c|c|c|c|c|c|}
\hline & 1 & 2 & 3 & 4 & 5 & 6 & 7 & 8 & 9 & 10 & 11 & 12 & 13 & 14 & 15 \\
\hline $1 \mathrm{CAR}(-3,+1)$ & 1.00 & & & & & & & & & & & & & & \\
\hline 2 MANUFACTURING & $0.21^{*}$ & 1.00 & & & & & & & & & & & & & \\
\hline 3 DEVELOPED & $0.31 * *$ & -0.03 & 1.00 & & & & & & & & & & & & \\
\hline 4 CD_PDI & 0.00 & -0.12 & 0.16 & 1.00 & & & & & & & & & & & \\
\hline 5 CD_IDV & 0.02 & -0.02 & 0.14 & $0.87 * * *$ & 1.00 & & & & & & & & & & \\
\hline 6 CD_MAS & 0.00 & -0.02 & $-0.41 * * *$ & $-0.30^{* *}$ & $-0.33 * * *$ & 1.00 & & & & & & & & & \\
\hline 7 CD_UAI & -0.11 & $0.27^{* *}$ & $-0.38 * * *$ & 0.03 & 0.15 & $0.54 * * *$ & 1.00 & & & & & & & & \\
\hline 8 CD_COMPOSITE & -0.02 & 0.06 & -0.08 & $0.79 * * *$ & $0.86 * * *$ & 0.07 & $0.57 * * *$ & 1.00 & & & & & & & \\
\hline 9 RELATEDNESS & -0.15 & $-0.31 * *$ & -0.02 & 0.13 & 0.10 & -0.04 & 0.05 & 0.09 & 1.00 & & & & & & \\
\hline 10 INDPRES & 0.01 & 0.10 & 0.15 & 0.08 & 0.06 & 0.04 & -0.09 & 0.04 & $-0.52 * * *$ & 1.00 & & & & & \\
\hline 11 COUNPRES & -0.03 & 0.12 & -0.01 & $0.26^{* *}$ & 0.21 & 0.17 & $0.30^{* *}$ & $0.33^{* * *}$ & 0.12 & 0.19 & 1.00 & & & & \\
\hline 12 RELATIVESIZE & -0.02 & -0.10 & -0.08 & -0.05 & -0.04 & -0.05 & -0.12 & -0.07 & -0.06 & -0.11 & $-0.36 * * *$ & 1.00 & & & \\
\hline $13 \mathrm{CASH}$ & -0.02 & $-0.28 * *$ & 0.06 & -0.06 & -0.09 & 0.16 & -0.12 & -0.09 & -0.12 & -0.06 & $-0.30^{* *}$ & 0.08 & 1.00 & & \\
\hline 14 PRIVATE & -0.14 & 0.20 & -0.10 & 0.21 & 0.11 & 0.00 & 0.07 & 0.13 & 0.18 & -0.06 & 0.19 & -0.15 & $-0.22 *$ & 1.00 & \\
\hline 15 PERCENTACQ & -0.02 & 0.05 & 0.04 & 0.14 & 0.06 & 0.03 & -0.03 & 0.08 & 0.12 & 0.05 & $0.23^{*}$ & 0.18 & -0.16 & 0.11 & 1.00 \\
\hline 16 STATE & 0.09 & $-0.46^{* * *}$ & -0.06 & 0.15 & 0.17 & -0.06 & -0.10 & 0.12 & 0.19 & -0.05 & $-0.23 *$ & $0.25^{*}$ & 0.10 & $-0.35^{* * * *}$ & -0.18 \\
\hline
\end{tabular}


Panel B: India

\begin{tabular}{|c|c|c|c|c|c|c|c|c|c|c|c|c|c|c|}
\hline & 1 & 2 & 3 & 4 & 5 & 6 & 7 & 8 & 9 & 10 & 11 & 12 & 13 & 14 \\
\hline $1 \mathrm{CAR}(-3,+1)$ & 1.00 & & & & & & & & & & & & & \\
\hline 2 SERVICES & $0.18 * *$ & 1.00 & & & & & & & & & & & & \\
\hline 3 DEVELOPED & $0.13^{*}$ & $0.13 *$ & 1.00 & & & & & & & & & & & \\
\hline 4 CD_PDI & 0.09 & 0.07 & $0.46 * * *$ & 1.00 & & & & & & & & & & \\
\hline 5 CD_IDV & $0.13^{*}$ & $0.19 * * *$ & $0.51 * * *$ & $0.47 * * *$ & 1.00 & & & & & & & & & \\
\hline 6 CD_MAS & $-0.12 *$ & $-0.14 *$ & $0.12 *$ & 0.05 & $-0.36 * * *$ & 1.00 & & & & & & & & \\
\hline 7 CD_UAI & -0.06 & $-0.13 *$ & $-0.22 * * *$ & $-0.71 * * *$ & $-0.71 * * *$ & $0.29 * * *$ & 1.00 & & & & & & & \\
\hline 8 CD_COMPOSITE & 0.09 & 0.03 & $0.67 * * *$ & $0.60 * * *$ & $0.44 * * *$ & $0.39 * * *$ & $-0.13 *$ & 1.00 & & & & & & \\
\hline 9 RELATEDNESS & 0.03 & $0.12 *$ & -0.07 & -0.06 & -0.06 & -0.01 & 0.07 & 0.01 & 1.00 & & & & & \\
\hline 10 INDPRES & 0.00 & -0.04 & 0.09 & 0.10 & 0.05 & 0.00 & -0.06 & 0.04 & $-0.61 * * *$ & 1.00 & & & & \\
\hline 11 COUNPRES & 0.08 & $-0.12 *$ & $-0.23 * * *$ & $-0.16^{* *}$ & $-0.32 * * *$ & $0.14 *$ & $0.24 * * *$ & $-0.13 *$ & 0.03 & 0.06 & 1.00 & & & \\
\hline 12 RELATIVESIZE & 0.04 & 0.01 & 0.05 & 0.02 & 0.09 & 0.05 & -0.10 & 0.00 & 0.00 & -0.02 & 0.05 & 1.00 & & \\
\hline $13 \mathrm{CASH}$ & 0.04 & -0.10 & 0.04 & -0.05 & -0.03 & -0.10 & 0.06 & -0.02 & $0.18^{* *}$ & $-0.21 * * *$ & -0.07 & $0.13 *$ & 1.00 & \\
\hline 14 PRIVATE & 0.09 & $0.19 * *$ & $0.16^{* *}$ & 0.06 & 0.05 & 0.04 & 0.05 & $0.19 * * *$ & -0.09 & 0.09 & 0.02 & $-0.16^{* *}$ & -0.07 & 1.00 \\
\hline 15 PERCENTACQ & -0.04 & 0.02 & -0.11 & $-0.13 *$ & -0.02 & -0.07 & 0.03 & $-0.12 *$ & $-0.12 *$ & 0.03 & -0.03 & 0.00 & 0.02 & 0.03 \\
\hline
\end{tabular}

CAR, cumulative abnormal return; DEVELOPED, developed target country; CD_PDI, "power distance index" cultural distance; CD_IDV, "individuality-collectivism" cultural distance; CD_MAS, “masculinity-femininity” cultural distance; CD_UAI, "uncertainty avoidance index" cultural distance; CD_COMPOSITE, composite index of cultural distance; RELATEDNESS, same-industry target; INDPRES, prior industry presence; COUNPRES, prior country presence; RELATIVESIZE, deal value divided by market value of bidder; CASH, cash-financed acquisition; PRIVATE, private target; PERCENTACQ, percent stake acquired in the transaction; STATE, state-owned bidder. $*, * *, * * *$ denote significance at $10 \%, 5 \%$ and $1 \%$ level. 
Table 4: Results of OLS regressions for Chinese deals (63 deals)

\begin{tabular}{|c|c|c|c|c|c|c|c|c|}
\hline & Model 1 & Model 2 & Model 3 & Model 4 & Model 5 & Model 6 & Model 7 & Model 8 \\
\hline MANUFACTURING & & $\begin{array}{l}0.0377 * * * \\
(2.71)\end{array}$ & & & & & & \\
\hline DEVELOPED & & & $\begin{array}{c}0.0537 * * \\
(2.54)\end{array}$ & & & & & \\
\hline CD_PDI & & & & $\begin{array}{r}0.0000 \\
(0.05)\end{array}$ & & & & \\
\hline CD_IDV & & & & & $\begin{array}{r}0.0000 \\
(0.04)\end{array}$ & & & \\
\hline CD_MAS & & & & & & $\begin{array}{l}0.0000 \\
(-0.03)\end{array}$ & & \\
\hline CD_UAI & & & & & & & $\begin{array}{r}-0.0003 \\
(-0.89)\end{array}$ & \\
\hline CD_COMPOSITE & & & & & & & & $\begin{array}{r}-0.0001 \\
(-0.35)\end{array}$ \\
\hline $\mathrm{CASH}$ & $\begin{array}{r}-0.0084 \\
(-0.55)\end{array}$ & $\begin{array}{r}0.0035 \\
(0.23)\end{array}$ & $\begin{array}{r}-0.0106 \\
(-0.74)\end{array}$ & $\begin{array}{r}-0.0060 \\
(-0.39)\end{array}$ & $\begin{array}{r}-0.0060 \\
(-0.38)\end{array}$ & $\begin{array}{r}-0.0059 \\
(-0.36)\end{array}$ & $\begin{array}{r}-0.0066 \\
(-0.43)\end{array}$ & $\begin{array}{r}-0.0057 \\
(-0.37)\end{array}$ \\
\hline RELATIVESIZE & $\begin{array}{l}-0.001 \\
(-1.04)\end{array}$ & $\begin{array}{l}-0.001 \\
(-1.34)\end{array}$ & $\begin{array}{r}-0.0007 \\
(-0.75)\end{array}$ & $\begin{array}{r}-0.0009 \\
(-1.01)\end{array}$ & $\begin{array}{r}-0.0009 \\
(-1.01)\end{array}$ & $\begin{array}{r}-0.0009 \\
(-1.02)\end{array}$ & $\begin{array}{r}-0.0009 \\
(-0.98)\end{array}$ & $\begin{array}{r}-0.0009 \\
(-1.36)\end{array}$ \\
\hline PERCENTACQ & $\begin{array}{r}0.0106 \\
(0.45)\end{array}$ & $\begin{array}{r}0.0116 \\
(0.49)\end{array}$ & $\begin{array}{r}0.0085 \\
(0.37)\end{array}$ & $\begin{array}{r}0.0136 \\
(0.57)\end{array}$ & $\begin{array}{r}0.0137 \\
(0.59)\end{array}$ & $\begin{array}{r}0.0138 \\
(0.6)\end{array}$ & $\begin{array}{r}0.0118 \\
(0.5)\end{array}$ & $\begin{array}{r}0.0141 \\
(0.59)\end{array}$ \\
\hline RELATEDNESS & $\begin{array}{l}-0.031 \\
(-1.38)\end{array}$ & $\begin{array}{r}-0.0169 \\
(-0.76)\end{array}$ & $\begin{array}{c}-0.0394 * \\
(-1.69)\end{array}$ & $\begin{array}{r}-0.0287 \\
(-1.33)\end{array}$ & $\begin{array}{r}-0.0287 \\
(-1.32)\end{array}$ & $\begin{array}{r}-0.0287 \\
(-1.32)\end{array}$ & $\begin{array}{r}-0.0297 \\
(-1.35)\end{array}$ & $\begin{array}{r}-0.0290 \\
(-1.4)\end{array}$ \\
\hline PRIVATE & $\begin{array}{r}-0.0124 \\
(-0.59)\end{array}$ & $\begin{array}{r}-0.0149 \\
(-0.69)\end{array}$ & $\begin{array}{r}-0.0053 \\
(-0.28)\end{array}$ & $\begin{array}{r}-0.0152 \\
(-0.75)\end{array}$ & $\begin{array}{r}-0.0151 \\
(-0.73)\end{array}$ & $\begin{array}{r}-0.0150 \\
(-0.7)\end{array}$ & $\begin{array}{r}-0.0152 \\
(-0.74)\end{array}$ & $\begin{array}{r}-0.0140 \\
(-0.8)\end{array}$ \\
\hline INDPRES & $\begin{array}{r}-0.0262 \\
(-1.07)\end{array}$ & $\begin{array}{r}-0.0196 \\
(-0.80)\end{array}$ & $\begin{array}{r}-0.0426 \\
(-1.65)\end{array}$ & $\begin{array}{r}-0.0280 \\
(-1.23)\end{array}$ & $\begin{array}{r}-0.0279 \\
(-1.22)\end{array}$ & $\begin{array}{r}-0.0279 \\
(-1.21)\end{array}$ & $\begin{array}{r}-0.0322 \\
(-1.36)\end{array}$ & $\begin{array}{r}-0.0283 \\
(-1.3)\end{array}$ \\
\hline COUNPRES & $\begin{array}{r}0.0021 \\
(0.09)\end{array}$ & $\begin{array}{r}0.0025 \\
(0.11)\end{array}$ & $\begin{array}{r}0.0069 \\
(0.36)\end{array}$ & $\begin{array}{r}0.0063 \\
(0.28)\end{array}$ & $\begin{array}{r}0.0064 \\
(0.29)\end{array}$ & $\begin{array}{r}0.0066 \\
(0.29)\end{array}$ & $\begin{array}{r}0.0115 \\
(0.52)\end{array}$ & $\begin{array}{r}0.0087 \\
(0.32)\end{array}$ \\
\hline STATE & $\begin{array}{r}0.0193 \\
(0.94)\end{array}$ & $\begin{array}{c}0.0352 * \\
(1.78)\end{array}$ & $\begin{array}{r}0.0252 \\
(1.29)\end{array}$ & $\begin{array}{r}0.0215 \\
(0.9)\end{array}$ & $\begin{array}{r}0.0215 \\
(0.89)\end{array}$ & $\begin{array}{r}0.0217 \\
(1.01)\end{array}$ & $\begin{array}{r}0.0213 \\
(1.01)\end{array}$ & $\begin{array}{r}0.0233 \\
(1.07)\end{array}$ \\
\hline Constant & $\begin{array}{r}0.0378 \\
(1.31)\end{array}$ & $\begin{array}{r}-0.0088 \\
(-0.30)\end{array}$ & $\begin{array}{r}-0.0061 \\
(-0.17)\end{array}$ & $\begin{array}{r}0.0318 \\
(1.12)\end{array}$ & $\begin{array}{r}0.0319 \\
(1.12)\end{array}$ & $\begin{array}{r}0.0322 \\
(1.07)\end{array}$ & $\begin{array}{r}0.0408 \\
(1.36)\end{array}$ & $\begin{array}{r}0.0350 \\
(1.38)\end{array}$ \\
\hline R-squared & 0.069 & 0.140 & 0.186 & 0.078 & 0.078 & 0.078 & 0.092 & 0.080 \\
\hline
\end{tabular}

The dependent variable is CAR $(-3,+1)$ in each regression. MANUFACTURING takes the value of one if the bidder's main activity is in the manufacturing industry, zero otherwise. DEVELOPED takes value of one if the host country is a member of the Organization for Economic Cooperation and Development and/or a member of the advanced economies list from the International Monetary Fund, zero otherwise. CD_PDI, CD_IDV, CD_MAS and CD_UAI are cultural distances between China and the target country in each individual dimension. CD_COMPOSITE is the composite index based on all four individual dimensions. CASH equals one if the acquisition is cash-financed, zero otherwise. RELATIVESIZE is the deal value divided by the bidder's market value pre-acquisition. PERCENTACQ is the percentage stake acquired through the transaction.

RELATEDNESS equals one if the target's main industry is the same as the acquirer, zero otherwise. PRIVATE equals one if the target is privately held, zero otherwise. INDPRES and COUNPRES are equal to one if the bidder previously acquired a company in the same industry (country) as the current target. STATE equals one if the bidder is state-owned, zero otherwise. T-statistics are reported in parenthesis, computed using heteroskedasticity-consistent standard errors.

$*, * *, * * *$ denote significance at $10 \%, 5 \%$ and $1 \%$ level. 
Table 5: Results of OLS regressions for Indian deals (203 deals)

\begin{tabular}{|c|c|c|c|c|c|c|c|c|}
\hline & Model 1 & Model 2 & Model 3 & Model 4 & Model 5 & Model 6 & Model 7 & Model 8 \\
\hline SERVICES & & $\begin{array}{l}0.0249 * * * \\
(2.66)\end{array}$ & & & & & & \\
\hline DEVELOPED & & & $\begin{array}{c}0.0218 * * \\
(2.14)\end{array}$ & & & & & \\
\hline CD_PDI & & & & $\begin{array}{r}0.0004 \\
(1.42)\end{array}$ & & & & \\
\hline CD_IDV & & & & & $\begin{array}{c}0.0009 * * \\
(2.43)\end{array}$ & & & \\
\hline CD_MAS & & & & & & $\begin{array}{l}-0.0012 * * \\
(-2.56)\end{array}$ & & \\
\hline CD_UAI & & & & & & & $\begin{array}{r}-0.0004 \\
(-1.53)\end{array}$ & \\
\hline CD_COMPOSITE & & & & & & & & $\begin{array}{r}0.0006 \\
(1.10)\end{array}$ \\
\hline CASH & $\begin{array}{r}0.0061 \\
(0.67)\end{array}$ & $\begin{array}{r}0.0094 \\
(1.06)\end{array}$ & $\begin{array}{r}0.0051 \\
(0.57)\end{array}$ & $\begin{array}{r}0.0046 \\
(0.5)\end{array}$ & $\begin{array}{r}0.0052 \\
(0.57)\end{array}$ & $\begin{array}{r}0.0021 \\
(0.23)\end{array}$ & $\begin{array}{r}0.0051 \\
(0.54)\end{array}$ & $\begin{array}{r}0.0042 \\
(0.46)\end{array}$ \\
\hline RELATIVESIZE & $\begin{array}{r}0.0105 \\
(0.39)\end{array}$ & $\begin{array}{r}0.0079 \\
(0.29)\end{array}$ & $\begin{array}{r}0.0081 \\
(0.31)\end{array}$ & $\begin{array}{r}0.0143 \\
(0.47)\end{array}$ & $\begin{array}{r}0.0106 \\
(0.35)\end{array}$ & $\begin{array}{r}0.0175 \\
(0.59)\end{array}$ & $\begin{array}{r}0.0130 \\
(0.43)\end{array}$ & $\begin{array}{r}0.0142 \\
(0.46)\end{array}$ \\
\hline PERCENTACQ & $\begin{array}{r}-0.0001 \\
(-0.41)\end{array}$ & $\begin{array}{r}-0.0001 \\
(-0.47)\end{array}$ & $\begin{array}{r}0.000 \\
(-0.19)\end{array}$ & $\begin{array}{l}0.0000 \\
(-0.11)\end{array}$ & $\begin{array}{r}-0.0001 \\
(-0.21)\end{array}$ & $\begin{array}{r}-0.0001 \\
(-0.39)\end{array}$ & $\begin{array}{r}-0.0001 \\
(-0.24)\end{array}$ & $\begin{array}{l}0.0000 \\
(-0.15)\end{array}$ \\
\hline RELATEDNESS & $\begin{array}{l}0.005 \\
(0.52)\end{array}$ & $\begin{array}{r}0.0002 \\
(0.03)\end{array}$ & $\begin{array}{r}0.0052 \\
(0.54)\end{array}$ & $\begin{array}{r}0.0071 \\
(0.74)\end{array}$ & $\begin{array}{r}0.0075 \\
(0.79)\end{array}$ & $\begin{array}{r}0.0064 \\
(0.7)\end{array}$ & $\begin{array}{r}0.0074 \\
(0.78)\end{array}$ & $\begin{array}{r}0.0064 \\
(0.66)\end{array}$ \\
\hline PRIVATE & $\begin{array}{r}0.0127 \\
(1.49)\end{array}$ & $\begin{array}{r}0.0078 \\
(0.93)\end{array}$ & $\begin{array}{r}0.0097 \\
(1.14)\end{array}$ & $\begin{array}{r}0.0102 \\
(1.17)\end{array}$ & $\begin{array}{r}0.0096 \\
(1.13)\end{array}$ & $\begin{array}{r}0.0119 \\
(1.38)\end{array}$ & $\begin{array}{r}0.0115 \\
(1.31)\end{array}$ & $\begin{array}{r}0.0088 \\
(1.00)\end{array}$ \\
\hline INDPRES & $\begin{array}{r}0.0038 \\
(0.26)\end{array}$ & $\begin{array}{r}0.0027 \\
(0.18)\end{array}$ & $\begin{array}{r}0.0017 \\
(0.11)\end{array}$ & $\begin{array}{r}0.0077 \\
(0.51)\end{array}$ & $\begin{array}{r}0.0083 \\
(0.53)\end{array}$ & $\begin{array}{r}0.0080 \\
(0.53)\end{array}$ & $\begin{array}{r}0.0087 \\
(0.57)\end{array}$ & $\begin{array}{r}0.0085 \\
(0.55)\end{array}$ \\
\hline COUNPRES & $\begin{array}{r}0.0098 \\
(1.07)\end{array}$ & $\begin{array}{r}0.0133 \\
(1.48)\end{array}$ & $\begin{array}{r}0.0139 \\
(1.48)\end{array}$ & $\begin{array}{r}0.0136 \\
(1.45)\end{array}$ & $\begin{array}{c}0.0185 * \\
(1.91)\end{array}$ & $\begin{array}{r}0.0139 \\
(1.46)\end{array}$ & $\begin{array}{r}0.0144 \\
(1.5)\end{array}$ & $\begin{array}{r}0.0129 \\
(1.36)\end{array}$ \\
\hline Constant & $\begin{array}{r}-0.0035 \\
(-0.35)\end{array}$ & $\begin{array}{r}-0.0085 \\
(-0.86)\end{array}$ & $\begin{array}{r}-0.0218 \\
(-1.61)\end{array}$ & $\begin{array}{r}-0.0190 \\
(-1.26)\end{array}$ & $\begin{array}{c}-0.0383 \text { ** } \\
(-2.12)\end{array}$ & $\begin{array}{r}0.0060 \\
(0.54)\end{array}$ & $\begin{array}{r}-0.0006 \\
(-0.06)\end{array}$ & $\begin{array}{r}-0.0369 \\
(-1.17)\end{array}$ \\
\hline R-squared & 0.022 & 0.055 & 0.038 & 0.032 & 0.047 & 0.043 & 0.031 & 0.029 \\
\hline
\end{tabular}

The dependent variable is CAR $(-3,+1)$ in each regression. SERVICES takes the value of one if the bidder's main activity is in the services industry, zero otherwise. DEVELOPED takes value of one if the host country is a member of the Organization for Economic Cooperation and Development and/or a member of the advanced economies list from the International Monetary Fund, zero otherwise. CD_PDI, CD_IDV, CD_MAS and CD_UAI are cultural distances between India and the target country in each individual dimension. CD_COMPOSITE is the composite index based on all four individual dimensions. CASH equals one if the acquisition is cash-financed, zero otherwise. RELATIVESIZE is the deal value divided by the bidder's market value pre-acquisition. PERCENTACQ is the percentage stake acquired through the transaction. RELATEDNESS equals one if the target's main industry is the same as the acquirer, zero otherwise. PRIVATE equals one if the target is privately held, zero otherwise. INDPRES and COUNPRES are equal to one if the bidder previously acquired a company in the same industry (country) as the current target. T-statistics are reported in parenthesis, computed using heteroskedasticity-consistent standard errors.

$*, * *, * * *$ denote significance at $10 \%, 5 \%$ and $1 \%$ level. 
Figure 1: Completed cross-border deals by Chinese firms from 2000 to 2010

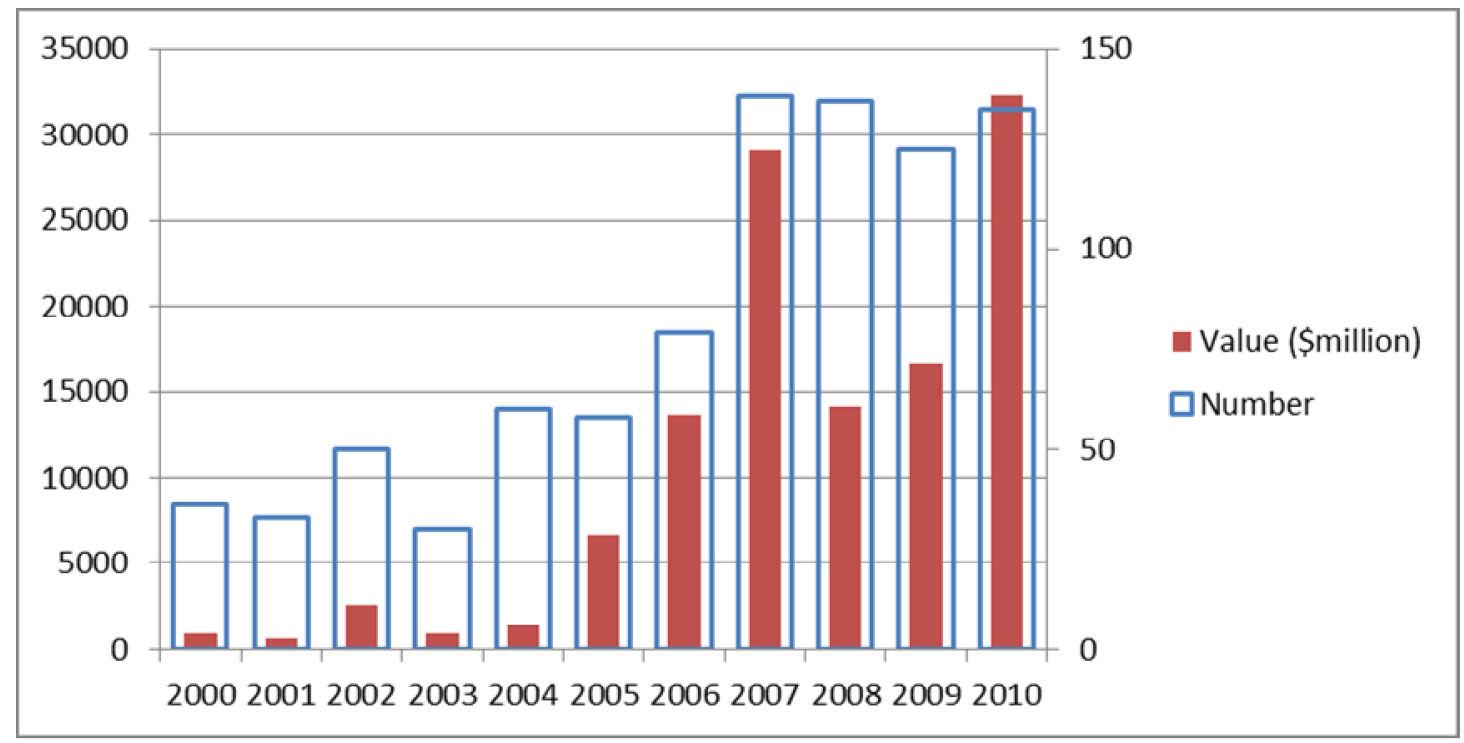

Source: Thomson One

Figure 2: Completed cross-border deals by Indian firms from 2000 to 2010

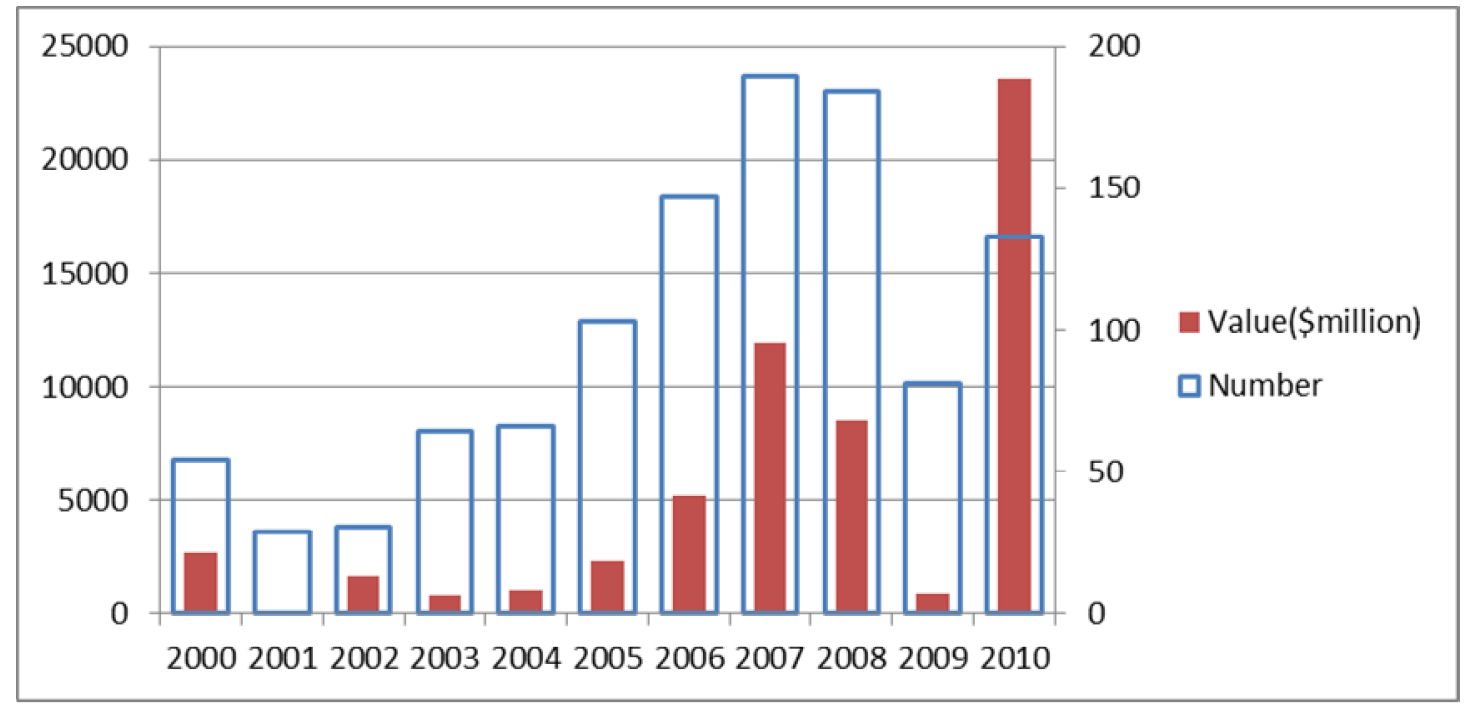

Source: Thomson One 